\title{
Bioethanol Production from Dilute-acid Pre-treated Wheat Straw Liquor Hydrolysate by Genetically Engineered Saccharomyces cerevisiae
}

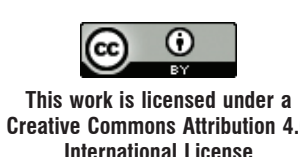
International License

\author{
N. Marđetko, ${ }^{a}$ M. Novak, ${ }^{a, *}$ A. Trontel, ${ }^{a}$ \\ M. Grubišić, ${ }^{a}$ M. Galić, ${ }^{b}$ and B. Šantek ${ }^{a}$ \\ aDepartment of Biochemical Engineering, \\ Faculty of Food Technology and Biotechnology, \\ University of Zagreb, Pierottijeva 6, 10000 Zagreb, Croatia \\ bDivision of Materials Chemistry, Ruđer Bošković Institute, \\ Bijenička cesta 54, 10000 Zagreb, Croatia
}

doi: 10.15255/CABEQ.2018.1409

Original scientific paper

Received: June 15, 2018

Accepted: December 7, 2018

\begin{abstract}
Sustainable recycling of lignocellulosic biomass includes utilization of all carbohydrates present in its hydrolysates. Since wheat straw is a xylose-rich raw material, utilization of xylose from obtained liquid part (liquor) of hydrolysates improves overall bioprocess efficiency. In this work, dilute acid pre-treatment of wheat straw was performed in high-pressure reactor at different temperatures $\left(160{ }^{\circ} \mathrm{C}-200{ }^{\circ} \mathrm{C}\right)$, residence times $(1$ $\min -10 \mathrm{~min})$, and acids $\left(\mathrm{H}_{2} \mathrm{SO}_{4}\right.$ and $\left.\mathrm{H}_{3} \mathrm{PO}_{4}\right)$ concentrations. During dilute acid pre-treatment, hemicellulose is degraded to pentose sugars that cannot be used by industrial ethanol-producing yeasts. Therefore, genetically engineered Saccharomyces cerevisiae strain that can utilize xylose was used. Fermentations were performed on different xylose-rich liquor wheat straw hydrolysates in shake-flasks and in horizontal rotating tubular bioreactor. The efficiency of fermentations carried out in shake flasks using xylose-rich liquor wheat straw hydrolysates were in the range of $19.61-74.51 \%$. However, the maximum bioprocess efficiency (88.24\%) was observed during fermentation in the HRTB on the liquor wheat straw hydrolysate obtained by pre-treatment with $2 \% \mathrm{w} / \mathrm{w}$ phosphoric acid.
\end{abstract}

Keywords

dilute acid pre-treatment, high-pressure reactor, wheat straw, xylose utilisation, bioethanol, genetically engineered Saccharomyces cerevisiae

\section{Introduction}

The world industry is trying to replace petrochemical fuels with fuels produced from renewable resources. The demand for ethanol is continuously increasing, because of not only the beverage and food industries, but also because ethanol is an alternative source of energy ${ }^{1}$. Bioethanol is a promising candidate for the replacement of petroleum-based fuels, since it can be used in cars without major modifications to the engine, it can be mixed with gasoline and thereby raise the fuels octane number. It is also environmentally friendly because of a higher degree of fuel combustion resulting in the reduction of carbon monoxide levels in the exhaust gases $^{2}$.

Sustainable fuel and chemical production processes should be based on raw materials that do not compete with human food and animal feed production, such as agricultural and forest biomass ${ }^{3}$. How-

"Corresponding author: Mario Novak; e-mail: mnovak@pbf.hr ever, the commercial production of ethanol uses starch and other sugar molasses for the fermentation process, bringing into question the viability of such processes since they are competing with the food industry ${ }^{2,4}$. Therefore, the most abundant renewable resource on Earth, lignocellulosic biomass, which is mostly considered waste, has been highlighted as a potential raw material for sustainable production of biofuels and biochemicals ${ }^{4}$. The building block of this biomass is lignocellulose, which is a compact and partially crystallized structure, built of three polymers, cellulose, hemicellulose, and lignin, which are interconnected by strong covalent and weak non-covalent bonds. Cellulose is composed of chains that contain units of D-glucose. These units are connected with a $\beta-1,4$-bond, while neighbouring chains are linked with hydrogen and Van der Waals bonds, forming a crystalline structure, thus inhibiting enzyme attainability ${ }^{5}$. Hemicellulose is more soluble than cellulose, and mainly consists of xylans. The two most abundant monosaccharides in its composition are xylose, which is interconnected 
with $\beta-1,4$ glycoside bonds, and L-arabinose ${ }^{6}$. Apart from those two most common sugars, hemicellulose contains other saccharides, such as mannose, galactose, and glucose, and organic acids, glucuronic, acetic, ferulic, and $p$-coumaric acid ${ }^{7,8}$. Hemicellulose is also covalently bonded to lignin and non-covalently to cellulose, which increases the overall stability of lignocellulose. Lignin is composed of phenylpropane units, which include coumaryl, coniferyl, and sinapyl alcohol. They are connected by ester links and form a crosslinked three-dimensional structure ${ }^{8}$.

It is obvious that lignocellulose is a chemically stable, robust, and complex material that is difficult to break down. To be able to use it in biotechnological processes, it is necessary to convert it into a form that can be enzymatically decomposed. Pre-treatment goals include elevation in porosity of the lignocellulosic raw material, removal of lignin and hemicellulose, and decrease in cellulose crystallinity. Accordingly, the methods used (either physical, physio-chemical, biological and chemical) in pre-treatment procedures must meet the following criteria: Formation of fermentable sugars during pre-treatment or increase in efficiency of later enzymatic hydrolysis; No degradation or loss of carbohydrates during the pre-treatment must occur; The formation of by-products that act as inhibitors of hydrolysis and/or fermentation processes should be avoided; Economic viability9.

Among all available methods, one of the most commonly used and most promising pre-treatments is the acidic pre-treatment. With this pre-treatment method, milled dry biomass is immersed in acidic solutions of different concentrations at certain temperatures and for different times. In acidic media, hemicellulose is hydrolysed to mono- and oligopolysaccharides due to the cleavage of glyosidic bonds between xylose units, while the amorphous region of cellulose is also degraded, leading to swelling of cellulose fibres $^{10,11}$. The most commonly used are sulphuric acids and phosphoric acid, because they are relatively inexpensive and efficient in the hydrolysis of lignocellulosic raw materials. However, efficiency of phosphoric acid hydrolysis is lower compared to that of sulphuric acid, but its use is environmentally more acceptable ${ }^{12}$. Even though acids are strong hydrolysing agents, they are extremely corrosive, toxic, and dangerous chemicals, which must be recycled after each pre-treatment. Therefore, dilute acid pre-treatment is generally carried out. The process takes place at elevated temperatures ranging from $140{ }^{\circ} \mathrm{C}$ to $215^{\circ} \mathrm{C}$, and residence time of several seconds to several minutes ${ }^{12,13}$. Sulphuric acid and phosphoric acid are predominantly used in this method in concentrations up to $4 \%(\mathrm{w} / \mathrm{w})$, resulting mainly in hemicellulose degradation, since the rate of hemicellulose hydrolysis is significantly faster than that of cellulose ${ }^{14}$. However, toxic compounds, which may negatively affect enzymatic hydrolysis and fermentation, can also be produced ${ }^{15}$. The concentration of toxic compounds is proportional to increasing pre-treatment temperatures and residence times. The resulting liquid hydrolysate must be neutralised, and if calcium carbonate is used, high amounts of gypsum are produced, which requires proper disposal, thus increasing the process costs.

After the pre-treatment process, the liquid hydrolysate undergoes fermentation. One of the most prominent and most commonly used microorganisms is Saccharomyces cerevisiae, which can convert sugars to ethanol as the main fermentation product ${ }^{16}$. Major drawbacks in the bioethanol production from lignocellulosic raw materials is that $S$. cerevisiae yeast has the ability to metabolize only certain monosaccharides and disaccharides, such as glucose, fructose, mannose, and sucrose, and is incapable of utilizing pentoses (e.g., xylose and arabinose) ${ }^{13}$. Genetic engineering techniques are being used to improve the properties of ethanol-producing microorganisms. Among them, genetically modified yeast strains of $S$. cerevisiae are more frequently used, which have the ability to metabolize xylose in order to maximize the ethanol yield ${ }^{17}$.

The focus of this research was to optimize weak acid (sulphuric acid and phosphoric acid) pre-treatment in high-pressure reactor (HPR) in order to obtain liquid part of the wheat straw hydrolysate (liquor wheat straw hydrolysate) that is rich in xylose, and the solid part rich in glucose. The pre-treatment was performed by different combinations of hydrolysis parameters (temperature, residence time, acid type and concentrations). Xylose-rich liquor wheat straw hydrolysate is usually discarded or burned for energy ${ }^{7}$, but it can also be efficiently used for bioethanol production. However, the solid part of wheat straw hydrolysate requires further treatment with enzyme cocktails in order to hydrolyse the remaining cellulose into glucose; however, this is not in the focus of this research. The potential of obtained liquor wheat straw hydrolysate for bioethanol production was also evaluated through the shake flasks experiments, and additionally confirmed through fermentations in horizontal rotating tubular bioreactor (HRTB).

\section{Materials and methods}

\section{Feedstock}

Wheat straw (92.61\% dry weight) obtained from northwest part of Croatia was used as feedstock. Prior to pre-treatment, wheat straw was re- 
duced in size using a hammer mill (NA45 Megametal d.o.o., Croatia). It was milled until all wheat straw particles reached a size less than $5 \mathrm{~mm}$. Wheat straw composition was determined by NREL method $^{18}$ : $51.90 \%$ glucans, $21.06 \%$ xylans, $5.12 \%$ arabinans, $3.04 \%$ acetic acid, $1.02 \%$ acid soluble lignin, $15.88 \%$ acid insoluble lignin and ash, and $2.0 \%(\mathrm{w} / \mathrm{w})$ other constituents.

\section{Dilute acid pre-treatment of wheat straw}

Wheat straw pre-treatment was performed in the HPR constructed as double jacket vessel (total volume of $20 \mathrm{~L}$ ) without stirrer and perforated holding vessel (slightly smaller diameter than reactor vessel) for grinded lignocellulosic feedstock. An amount of $500 \mathrm{~g}$ of dry weight milled wheat straw was transferred into HPR and suspended in $10 \mathrm{~L}$ of dilute sulphuric acid $(0.5 \% \mathrm{w} / \mathrm{w})$ or phosphoric acid $(2.0 \% \mathrm{w} / \mathrm{w})$. Solid-to-liquid ratio of 1:20 was obtained and used throughout the research. In preliminary research, pre-treatment experiments with diluted sulphuric acid $(0.5 \% \mathrm{w} / \mathrm{w})$ and phosphoric acid $(w=2.0 \% \mathrm{w} / \mathrm{w})$ were carried out at different temperatures $\left(150{ }^{\circ} \mathrm{C}-200{ }^{\circ} \mathrm{C}\right)$ and constant residence time of $5 \mathrm{~min}$ (data not shown). On the basis of these experiments, it was decided that temperature range in further research will be $160{ }^{\circ} \mathrm{C}-200{ }^{\circ} \mathrm{C}$ with different residence times (1-10 minutes, $t_{\mathrm{R}}$; see Tables 1 and 2). After pre-treatment, two fractions were obtained, liquor hydrolysate (liquid fraction), and residual solid fraction of wheat straw. Wheat straw hydrolysate was neutralized with $\mathrm{Ca}(\mathrm{OH})_{2}$ to approximately $\mathrm{pH} 7$, left to settle, after which the liquid part of the hydrolysate was decanted. Solid part of the slurry was then rinsed with distilled water until $\mathrm{pH} 7$ was reached. Both fractions were stored and analysed for their composition, and kept at $-20{ }^{\circ} \mathrm{C}$ for future research. In this research, neutralized liquor wheat straw hydrolysate was used in fermentations to evaluate its potential for bioethanol production.

\section{Working microorganism and media}

In this work, genetically engineered yeast $\mathrm{Sac}$ charomyces cerevisiae that can utilize xylose, from the collection of Laboratory for Biochemical Engineering, Industrial Microbiology and Malting and Brewing Technology (Faculty of Food Technology and Biotechnology, University of Zagreb) was used as a working microorganism. Its genetic stability was proven during intensive preliminary research (data not shown). Medium composition used for inoculum preparation was composed of (in $\mathrm{g} \mathrm{L}^{-1}$ ): glucose 50.0; yeast extract 1.5; $\left(\mathrm{NH}_{4}\right)_{2} \mathrm{HPO}_{4}$ 1.0; $\left(\mathrm{NH}_{4}\right)_{2} \mathrm{SO}_{4}$ 1.0. Composition of the control medium for aerobic and anaerobic cultivation of genetically engineered $S$. cerevisiae was as follows (in $\left.\mathrm{g} \mathrm{L}^{-1}\right)$ : glucose 7.0 ; xylose 6.0 ; yeast extract 1.5; $\left(\mathrm{NH}_{4}\right)_{2} \mathrm{HPO}_{4} 1.0 ;\left(\mathrm{NH}_{4}\right)_{2} \mathrm{SO}_{4} 1$.

Liquor wheat straw hydrolysate media were supplemented with the same amounts of yeast extract, $\left(\mathrm{NH}_{4}\right)_{2} \mathrm{HPO}_{4}$ and $\left(\mathrm{NH}_{4}\right)_{2} \mathrm{SO}_{4}$ as in control medium. These cultivation media were used in Erlenmeyer-flasks fermentation experiments. In fermentations carried out in the HRTB, liquor wheat straw hydrolysate media were supplemented with yeast extract, $\left(\mathrm{NH}_{4}\right)_{2} \mathrm{HPO}_{4}$ and $\left(\mathrm{NH}_{4}\right)_{2} \mathrm{SO}_{4}$ and glucose $\left(10 \mathrm{~g} \mathrm{~L}^{-1}\right)$ in order to support xylose utilization. Viable cell count was determined as CFU $\mathrm{mL}^{-1}$ on malt agar medium (Biolife, Italy). Prior to inoculation, all media were sterilized at $121{ }^{\circ} \mathrm{C}$ for 20 minutes and cooled to room temperature.

\section{Bioethanol production in different cultivation systems}

Preliminary aerobic and anaerobic cultivations of genetically engineered yeast $S$. cerevisiae were performed in Erlenmeyer flasks containing $300 \mathrm{~mL}$ medium. All media were inoculated with $10 \%(\mathrm{v} / \mathrm{v})$ inoculum grown overnight. Aerobic and anaerobic cultivations were performed at $25{ }^{\circ} \mathrm{C}$ without $\mathrm{pH}$ control. Thereafter, HRTB with total volume of $30 \mathrm{~L}$ was used for fermentation experiments. Two paddles attached to rotating bioreactor wall ensured mixing and homogenization of the medium. HRTB was made of stainless steel and equipped with a system for temperature and pressure monitoring, as well as a rotation system with two different operating (continuous or interval) modes. Interval rotation mode of HRTB is characterised by its ability to define bioreactor rotation/stagnation time. The optimal operating conditions of HRTB for bioethanol production have been previously defined ${ }^{19}$, and are characterised by HRTB interval rotation mode (12 $\mathrm{min} / 20 \mathrm{~min}^{-1}$ meaning 1 hour 12 minutes of HRTB rotation at $20 \mathrm{~min}^{-1}$, and 48 minutes of HRTB stagnation (non-rotation period). The sterilization of HRTB was performed by direct steam $\left(121^{\circ} \mathrm{C} / 20\right.$ $\mathrm{min}$ ). Total volume of liquor wheat straw hydrolysate media in the HRTB was $5 \mathrm{~L}$, and bioreactor was inoculated with $10 \%(\mathrm{v} / \mathrm{v})$ of yeast suspension grown overnight. Fermentations were performed at $25^{\circ} \mathrm{C}$, samples were withdrawn from the HRTB or flasks at regular time intervals, and analysed.

\section{Analytical methods}

Analysis of wheat straw composition and wheat straw hydrolysate, both liquid and solid phase, for determination of structural carbohydrates, acid soluble and acid insoluble lignin, acetic acid and insoluble residue was performed according to NREL method $^{18}$. Concentrations of furans (furfural and hy- 
droxymethylfurfural) were determined in supernatants of samples according to Martinez et al. ${ }^{20}$ Acid insoluble lignin in wheat straw and pre-treated wheat straw was determined by standard TAPPI method $^{18}$, while acid soluble lignin was determined in the wheat straw hydrolysate spectrophotometrically at wavelength of $205 \mathrm{~nm}$ by standard TAPPI method $^{18}$.

Fermentation broth samples were used for determination of optical density at $600 \mathrm{~nm}$ and for viable cell count plating on malt agar medium $\left(30^{\circ} \mathrm{C} /\right.$ $48 \mathrm{~h})$. The samples were then centrifuged (4500 $\mathrm{rpm} / 20 \mathrm{~min} / 4{ }^{\circ} \mathrm{C}$; Harrier 18/80, Sanyo, UK), and the supernatant was pre-treated prior to HPLC determination of carbohydrates (glucose, xylose, arabinose), glycerol, levulinic, acetic, formic acid, and ethanol concentrations.

Briefly, from the supernatants, proteins were precipitated with zinc sulphate solution $(g=$ $\left.100 \mathrm{~g} \mathrm{~L}^{-1}\right)^{21}$ and centrifuged to remove the proteins (10000 $\mathrm{min}^{-1} / 10 \mathrm{~min} / 4{ }^{\circ} \mathrm{C}$; Harrier 18/80, Sanyo, UK). Obtained supernatants were filtered through $0.22 \mathrm{~mm}$ nylon syringe filter (LAB Logistics Group $\mathrm{GmbH}$, USA), and used for HPLC analysis (CLASS-VP LC-10A VP; Shimadzu, Kyoto, Japan) on chromatograph equipped with ion-exchange column Supelcogel ${ }^{\mathrm{TM}}$ C-610 Hand guard column (Supelogel ${ }^{\mathrm{TM}} \mathrm{H}$ ), as well as RID detector. Separation and elution was performed with phosphoric acid $(0.1 \% \mathrm{w} / \mathrm{w})$ at flow rate of $0.5 \mathrm{~mL} \mathrm{m^{-1 }}$, column temperature of $55^{\circ} \mathrm{C}$.

\section{Bioprocess efficiency parameters}

Bioprocess efficiency parameters were determined by standard procedures. Ethanol content was determined by the following equation:

Ethanol content $=$ final ethanol content

- initial ethanol content $\left(\mathrm{g} \mathrm{L}^{-1}\right)$

Ethanol yield $\left(Y_{\mathrm{E}}\right)$ was calculated by the following equation:

$Y_{\mathrm{E}}=\frac{\text { grams of ethanol produced }}{\text { grams of sugars consumed }}$

Bioprocess efficiency $(E)$ was estimated as the percentage of the ratio between experimental $Y_{E}$ and theoretical ethanol yield:

$$
E=Y_{\mathrm{E}} \cdot 100 / \text { theoretical ethanol yield }
$$

where theoretical ethanol yield is $0.51 \mathrm{~g} \mathrm{~g}^{-1} 31,32$.

Volumetric ethanol productivity (VEP) was determined by the following equation:

$$
\mathrm{VEP}=Y_{E} / t
$$

where $t$ is cultivation time.
Substrate consumption rate $\left(r_{\mathrm{S}} ; \mathrm{h}^{-1}\right)$, specific growth rate $\left(\mu ; \mathrm{h}^{-1}\right)$, and ethanol production rate $\left(r_{\mathrm{p}} ;\right.$ $\mathrm{h}^{-1}$ ) were determined as a first-order reaction ${ }^{22,23} \mathrm{us}_{\mathrm{s}}$ ing data from exponential phase. The data were linearized according to the following equation:

$$
\begin{aligned}
& \ln S=\ln S_{0}+r_{\mathrm{S}} \cdot t \\
& \ln X=\ln X_{0}+\mu \cdot t \\
& \ln P=\ln P_{0}+r_{\mathrm{P}} \cdot t
\end{aligned}
$$

and $r_{\mathrm{S}}, \mu$ and $r_{\mathrm{p}}$ were determined as the slope of the linearized regression line.

\section{Results and discussion}

In this work, liquor wheat straw hydrolysate, obtained after dilute acid pre-treatment of wheat straw in the HPR, was examined for bioethanol production. It contains mainly pentose sugars (e.g. xylose and arabinose) and other sugars due to the hemicellulose degradation in the pre-treatment. Except sugars, obtained liquor wheat straw hydrolysate contains several other compounds, such as acids (acetic, formic, and levulinic acids), furans (furfural and hydroxymethylfurfural - HMF), and different lignin derivatives that can have inhibitory effect on the working microorganism in bioethanol production $^{24,25}$. Solid part of wheat straw hydrolysate contains mainly cellulose and insoluble lignin, and it can be further hydrolysed by commercial enzyme cocktails for lignocellulose degradation into fermentable sugars. In preliminary research, different solid-to-liquid ratios $(1: 5-1: 20)$ were examined for wheat straw pre-treatment, and it was observed that ratio of $1: 20$ is the most suitable for wheat straw pre-treatment in HPR, due to the lowest production of fermentation inhibitors and efficiency of wheat straw hydrolysis (data not shown). Therefore, solid-to-liquid ratio of 1:20 was constant throughout the research. It is well known that, for successful pre-treatment of lignocellulosic feedstock, the soaking process is required prior to pre-treatment. In this study, an innovative approach was examined, which combines soaking and pre-treatment occurring in parallel in the HPR. After loading the milled wheat straw in the perforated holding vessel of the HPR, solution of weak acid was added and wheat straw was covered with dilute acid solution. During temperature increase in the HPR to obtain pre-treatment temperature $(30-40$ minutes to operating conditions), soaking of the wheat straw and liquid pre-treatment took place, and once the operating temperature was achieved, treatment was conducted for the defined time interval. 
The focus of this research was to evaluate the potential of liquor wheat straw hydrolysate for bioethanol production, as well as to estimate its impact on bioethanol production in biorefinery system. Since $S$. cerevisiae yeast cannot utilize pentose sugars as main carbon source ${ }^{25}$, in this work, the genetically engineered $S$. cerevisiae yeast that can utilize xylose and has tolerance to toxic compounds present in the lignocellulosic hydrolysates, was used to improve overall bioethanol production efficiency.

\section{Dilute acid pre-treatment of wheat straw in the HPR}

In this study, dilute acid pre-treatment was performed using sulphuric acid $(0.5 \% \mathrm{w} / \mathrm{w})$ and phosphoric acid $(2.0 \% \mathrm{w} / \mathrm{w})$. Sulphuric acid and phosphoric acid concentrations used in the pre-treatment process were optimized in a prior set of experiments (data not shown). The efficiency of wheat straw hydrolysis was presented as a saccharification yield (percentage of hydrolysed glucans, xylans or arabinans compared to their initial content in the wheat straw). Saccharification yields of wheat straw obtained after its pre-treatment using dilute sulphuric acid $(0.5 \% \mathrm{w} / \mathrm{w})$ and phosphoric acid $(2.0 \% \mathrm{w} / \mathrm{w})$ in the HPR are presented in Figs. 1 and 2, respectively. As may be seen in Fig. 1, glucose concentration in the liquor wheat straw hydrolysate was in the range of $1.15-4.84 \mathrm{~g} \mathrm{~L}^{-1}$ (Table 1; glucan saccharification yield from 2.64 to $9.64 \%$ ). Xylose concentration in the liquor wheat straw hydrolysate was considerably higher than glucose, and it was in the range of $4.35-13.00 \mathrm{~g} \mathrm{~L}^{-1}$ (Table 1). Saccharification yield of xylans was from 18.33 to $66.25 \%$ of total xylans available in the raw wheat straw. Arabinose concentration in the hydrolysate was from 0.76 to $1.72 \mathrm{~g} \mathrm{~L}^{-1}$ (Fig. 1, Table 1; arabinan saccharification yield, $12.82-37.48 \%$ ). During dilute acid pre-treatment, mostly hemicellulose is degraded ${ }^{26}$ and it was expected that liquor wheat straw hydrolysate will generally contain pentose sugars, smaller amount of hexose sugars and acetic acid. The highest saccharification yields of xylose (45.43 - $51.42 \%)$ and arabinose $(31.03-37.48 \%)$ were observed at $180{ }^{\circ} \mathrm{C}$ (Fig. 1). At temperatures of $160{ }^{\circ} \mathrm{C}$ and $200^{\circ} \mathrm{C}$, lower saccharification yields of these two pentose sugars were accomplished. Temperature of $160{ }^{\circ} \mathrm{C}$ probably was not high enough to facilitate the hemicellulose hydrolysis. Yield of these two sugars in the liquor wheat straw hydrolysate was lower than the yield at $180{ }^{\circ} \mathrm{C}$. At temperature of $200{ }^{\circ} \mathrm{C}$, hemicellulose was hydrolysed to pentose sugars with lower yield than at $180^{\circ} \mathrm{C}$ (Fig. $1)$. It is known that, at higher temperatures, pentose and hexose sugars are converted to furfural and hydroxymethylfurfural (HMF), which can be further degraded to formic and levulinic acid ${ }^{26}$. Concentra- tion of these compounds varies depending on the pre-treatment conditions (Table 2) ${ }^{27-30}$, and they can affect bioprocess efficiency to a lower or higher extent ${ }^{26}$. Obtained data for pre-treatment at $200{ }^{\circ} \mathrm{C}$ (Table 2) showed relatively high furan (705.53 $\left.929.49 \mathrm{mg} \mathrm{L}^{-1}\right)$ and formic acid concentrations $(0.96$ $\left.-1.49 \mathrm{~g} \mathrm{~L}^{-1}\right)$, and low levulinic acid concentrations $\left(0.06-0.08 \mathrm{~g} \mathrm{~L}^{-1}\right)$ that was not detected at other tested temperatures. Based on these results, it is obvious that, at $200{ }^{\circ} \mathrm{C}$, significant hemicellulose degradation was achieved. Other than monomeric sugars, acetic acid is formed during hemicellulose hydrolysis with concentrations in the range of 0.43 $1.08 \mathrm{~g} \mathrm{~L}^{-1}$. Dilute phosphoric acid pre-treatment of wheat straw was performed at the same process conditions as dilute sulphuric acid pre-treatment (Table 1). Concentrations of monomeric sugars present in dilute phosphoric acid hydrolysate are shown in Table 1. Observed glucose concentrations were similar to those obtained for dilute sulphuric acid pre-treatment, and they were in the range of $2.26-5.55 \mathrm{~g} \mathrm{~L}^{-1}$. Xylose concentrations were in the range of $3.12-9.07 \mathrm{~g} \mathrm{~L}^{-1}$, and maximum attainable concentration was lower than the same value obtained for sulphuric acid pre-treatment $\left(\gamma_{\text {xylose }}=\right.$ $13.00 \mathrm{~g} \mathrm{~L}^{-1}$; Table 1). Obtained arabinose concentrations $\left(0.56-1.69 \mathrm{~g} \mathrm{~L}^{-1}\right)$ were in the similar range as observed for sulphuric acid pre-treatment (Table 1). Saccharification yield of glucans in the phosphoric acid hydrolysate were in the range of $5.48-$ $10.41 \%$ (Fig. 2), while xylan saccharification yields in the wheat straw hydrolysate were in the range of $13.37-52.89 \%$, and arabinose saccharification in yield $11.84-40.79 \%$, respectively (Fig. 2). The highest yield of hemicellulose-derived sugars (xylose and arabinose) was also observed at $180{ }^{\circ} \mathrm{C}$. Acetic acid concentration in the wheat straw hydrolysate was in the range of $0.66-1.03 \mathrm{~g} \mathrm{~L}^{-1}$ (Table 2). Observed data are similar to data obtained for dilute sulphuric acid pre-treatment. Higher concentrations of furans $\left(850.96-1268.43 \mathrm{mg} \mathrm{L}^{-1}\right.$; Table 2) were detected for phosphoric acid pre-treatment at $200{ }^{\circ} \mathrm{C}$ than for sulphuric acid pre-treatment (705.53 - $929.49 \mathrm{mg} \mathrm{L}^{-1}$; Table 2). It is well known that furfural and hydroxymethylfurfural (HMF) are formed from pentose and hexose sugars, respectively, in acidic conditions and high temperature ${ }^{34,37-39}$. Prolonged exposure to these harsh conditions leads to further degradation of furfural and HMF to formic acid (and levulinic acid from HMF). Therefore, reduction of furfural levels can be due to this reaction, and additionally due to evaporation caused by prolonged residence time. Formic acid concentration $\left(0.71-0.98 \mathrm{~g} \mathrm{~L}^{-1}\right)$ was lower in the phosphoric acid pre-treatment than in the sulphuric acid pre-treatment. Levulinic acid was also detected in the liquor wheat straw hydrolysates after phosphoric acid pre-treatment at $200{ }^{\circ} \mathrm{C}\left(0.06-0.13 \mathrm{~g} \mathrm{~L}^{-1}\right)$. 
Table 1 -Concentrations of monomeric sugars in the liquor wheat straw hydrolysate after dilute acid pre-treatment in the HPR

\begin{tabular}{|c|c|c|c|c|c|c|c|}
\hline \multirow{3}{*}{$\begin{array}{c}t \\
\left({ }^{\circ} \mathrm{C}\right)\end{array}$} & \multirow{3}{*}{$\begin{array}{l}\text { Time } \\
(\min )\end{array}$} & \multicolumn{6}{|c|}{$w_{\text {acid }}(\% \mathrm{w} / \mathrm{w})$} \\
\hline & & \multicolumn{3}{|c|}{$0.5 \%$ sulphuric acid } & \multicolumn{3}{|c|}{$2.0 \%$ phosphoric acid } \\
\hline & & $\begin{array}{c}\text { Glucose } \\
\left(\mathrm{g} \mathrm{L}^{-1}\right)\end{array}$ & $\begin{array}{l}\text { Xylose } \\
\left(\mathrm{g} \mathrm{L}^{-1}\right)\end{array}$ & $\begin{array}{c}\text { Arabinose } \\
\left(\mathrm{g} \mathrm{L}^{-1}\right)\end{array}$ & $\begin{array}{c}\text { Glucose } \\
\left(\mathrm{g} \mathrm{L}^{-1}\right)\end{array}$ & $\begin{array}{l}\text { Xylose } \\
\left(\mathrm{g} \mathrm{L}^{-1}\right)\end{array}$ & $\begin{array}{c}\text { Arabinose } \\
\left(\mathrm{g} \mathrm{L}^{-1}\right)\end{array}$ \\
\hline \multirow{3}{*}{160} & 1 & 1.15 & 4.86 & 1.20 & 2.26 & 6.14 & 1.39 \\
\hline & 5 & 1.92 & 13.00 & 1.68 & 2.35 & 9.07 & 1.65 \\
\hline & 10 & 2.24 & 7.64 & 1.56 & 3.75 & 6.08 & 1.24 \\
\hline \multirow{3}{*}{180} & 1 & 3.52 & 8.33 & 1.49 & 3.86 & 9.24 & 1.69 \\
\hline & 5 & 2.17 & 9.06 & 1.47 & 3.44 & 5.03 & 1.19 \\
\hline & 10 & 3.52 & 9.96 & 1.72 & 4.26 & 8.00 & 1.52 \\
\hline \multirow{3}{*}{200} & 1 & 4.28 & 7.49 & 1.51 & 3.03 & 3.40 & 0.72 \\
\hline & 5 & 4.73 & 4.57 & 0.76 & 5.55 & 2.96 & 0.62 \\
\hline & 10 & 4.84 & 4.35 & 1.14 & 4.09 & 3.12 & 0.56 \\
\hline
\end{tabular}

Table 2 -Concentrations of inhibitors in the liquor wheat straw hydrolysates formed during dilute acid pre-treatments in the HPR

\begin{tabular}{|c|c|c|c|c|c|c|c|c|c|c|c|}
\hline \multirow{3}{*}{$\begin{array}{c}t \\
\left({ }^{\circ} \mathrm{C}\right)\end{array}$} & \multirow{3}{*}{$\begin{array}{l}\text { Time } \\
(\min )\end{array}$} & \multicolumn{10}{|c|}{$w_{\text {acid }}(\% \mathrm{w} / \mathrm{w})$} \\
\hline & & \multicolumn{5}{|c|}{$0.5 \% \mathrm{w} / \mathrm{w}$ sulphuric acid } & \multicolumn{5}{|c|}{$2.0 \% \mathrm{w} / \mathrm{w}$ phosphoric acid } \\
\hline & & $\begin{array}{c}\text { Formic } \\
\text { acid } \\
\left(\mathrm{g} \mathrm{L}^{-1}\right)\end{array}$ & $\begin{array}{l}\text { Acetic } \\
\text { acid } \\
\left(\mathrm{g} \mathrm{L}^{-1}\right)\end{array}$ & $\begin{array}{c}\text { Levulinic } \\
\text { acid } \\
\left(\mathrm{g} \mathrm{L}^{-1}\right)\end{array}$ & $\begin{array}{l}\text { Furans } \\
\left(\mathrm{mg} \mathrm{L}^{-1}\right)\end{array}$ & $\begin{array}{l}\text { LSA } \\
(\%)\end{array}$ & $\begin{array}{c}\text { Formic } \\
\text { acid } \\
\left(\mathrm{g} \mathrm{L}^{-1}\right)\end{array}$ & $\begin{array}{l}\text { Acetic } \\
\text { acid } \\
\left(\mathrm{g} \mathrm{L}^{-1}\right)\end{array}$ & $\begin{array}{c}\text { Levulinic } \\
\text { acid } \\
\left(\mathrm{g} \mathrm{L}^{-1}\right)\end{array}$ & $\begin{array}{c}\text { Furans } \\
\left(\mathrm{mg} \mathrm{L}^{-1}\right)\end{array}$ & $\begin{array}{l}\text { LSA } \\
(\%)\end{array}$ \\
\hline \multirow{3}{*}{160} & 1 & 0.57 & 0.43 & 0 & 61.69 & 1.85 & 0.75 & 0.66 & 0 & 58.49 & 1.06 \\
\hline & 5 & 0.34 & 0.96 & 0 & 278.45 & 0.49 & 0.72 & 0.76 & 0 & 137.42 & 1.12 \\
\hline & 10 & 0.59 & 0.56 & 0 & 77.32 & 1.76 & 0.83 & 0.73 & 0 & 52.48 & 0.97 \\
\hline \multirow{3}{*}{180} & 1 & 0.80 & 0.77 & 0 & 249.20 & 1.99 & 0.95 & 1.03 & 0 & 374.20 & 2.18 \\
\hline & 5 & 1.01 & 0.88 & 0 & 906.65 & 0.92 & 1.13 & 0.95 & 0 & 678.29 & 0.84 \\
\hline & 10 & 1.01 & 1.08 & 0 & 225.16 & 1.84 & 1.02 & 1.03 & 0 & 393.03 & 2.04 \\
\hline \multirow{3}{*}{200} & 1 & 1.32 & 1.08 & 0 & 705.53 & 0.97 & 0.66 & 0.71 & 0.06 & 1268.43 & 1.77 \\
\hline & 5 & 0.96 & 0.59 & 0.06 & 868.99 & 1.65 & 1.11 & 0.82 & 0.16 & 850.96 & 0.94 \\
\hline & 10 & 1.49 & 1.02 & 0.08 & 929.49 & 1.83 & 0.86 & 0.98 & 0.13 & 1027.24 & 1.59 \\
\hline
\end{tabular}

LSA - lignin soluble in acid

Solid part of wheat straw obtained after dilute sulphuric acid and phosphoric acid pre-treatment was composed mainly of glucans and acid-insoluble lignin (data not shown). It was not used in these fermentation experiments because it has to be hydrolysed to fermentable sugars by cellulolytic enzymes.

\section{Aerobic and anaerobic cultivations of genetically engineered $S$. cerevisiae on different control media in shake flasks}

This set of preliminary experiments was performed in order to define bioprocess efficiency parameters (Table 3) for aerobic and anaerobic cultivations of genetically engineered $S$. cerevisiae performed in the nutrient-rich media containing only glucose or glucose and xylose as a carbon source. This yeast strain does not grow or utilize xylose when xylose is the sole carbon and energy source present in the medium (data not shown).

When grown in medium containing only glucose in aerobic conditions (Fig. 3a), all of the glucose was consumed in $7 \mathrm{~h}$ at consumption rate of $0.47 \mathrm{~h}^{-1}$ (Table 3), while during anaerobic cultivation, even after $24 \mathrm{~h}$ of cultivation, glucose was present in the medium (Fig. 3b). Glucose consumption rate in the anaerobic cultivation was approximately one-fifth of that under anaerobic cultivation $\left(0.09 \mathrm{~h}^{-1}\right)$. The maximum specific growth rate $\left(\mu_{\max }\right)$ in aerobic $\left(0.24 \mathrm{~h}^{-1}\right)$ was slightly higher than in 

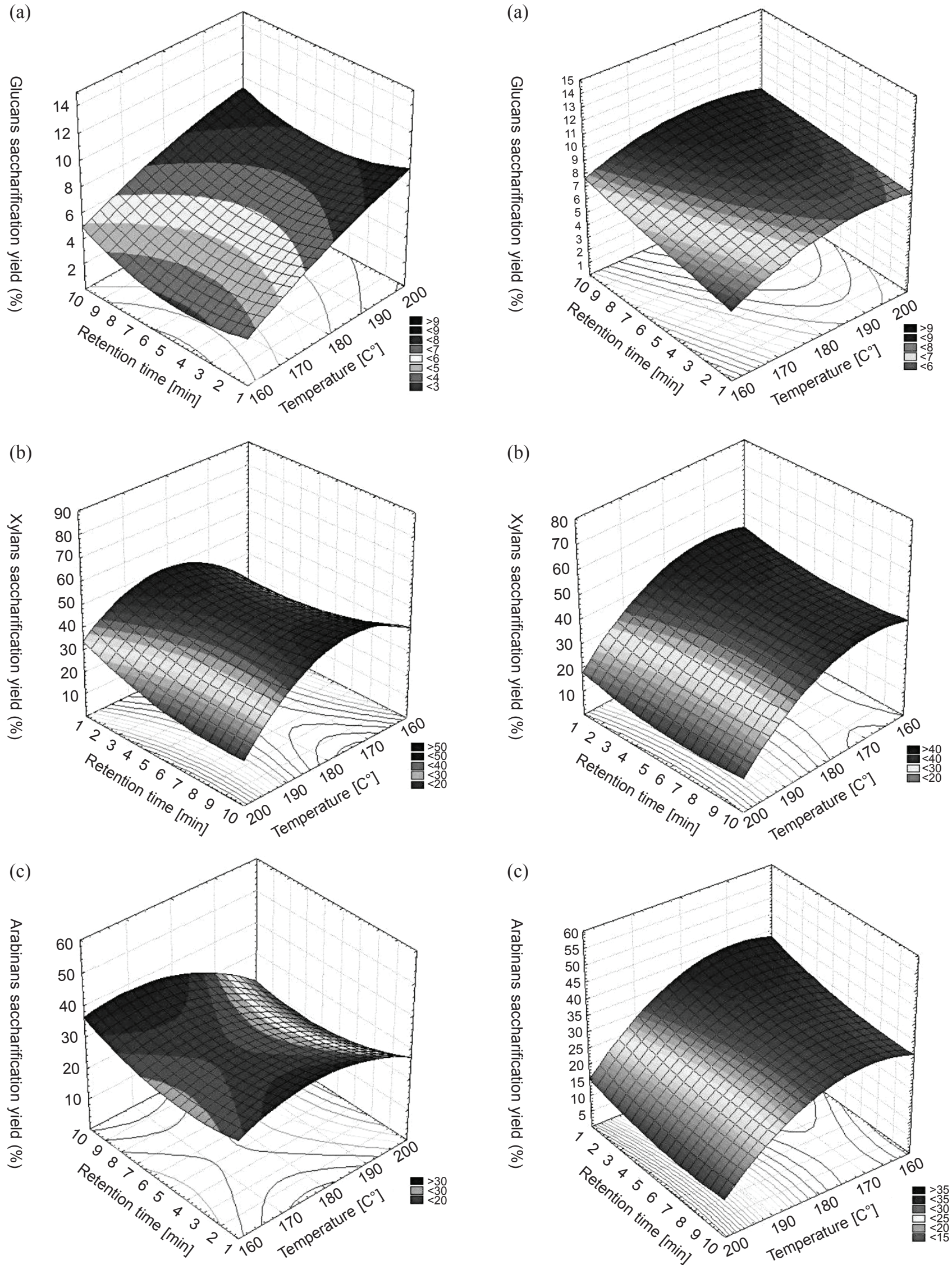

Fig. 1 - Saccharification yield of: a) glucans, b) xylans, and c) arabinans in the liquor wheat straw hydrolysate after diluted sulphuric acid $(0.5 \% \mathrm{w} / \mathrm{w})$ pre-treatment by different combination of hydrolysis process parameters in the HPR

Fig. 2 - Saccharification yield of: a) glucans, b) xylans, and c) arabinans in the liquor wheat straw hydrolysate after diluted phosphoric acid $(2.0 \% \mathrm{w} / \mathrm{w})$ pre-treatment by different combination of hydrolysis process parameters in the HPR 
(a)

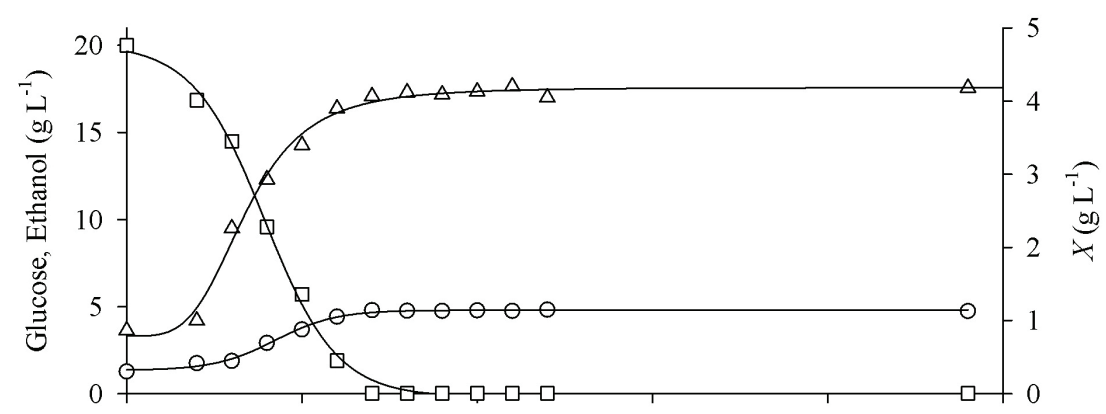

(b)

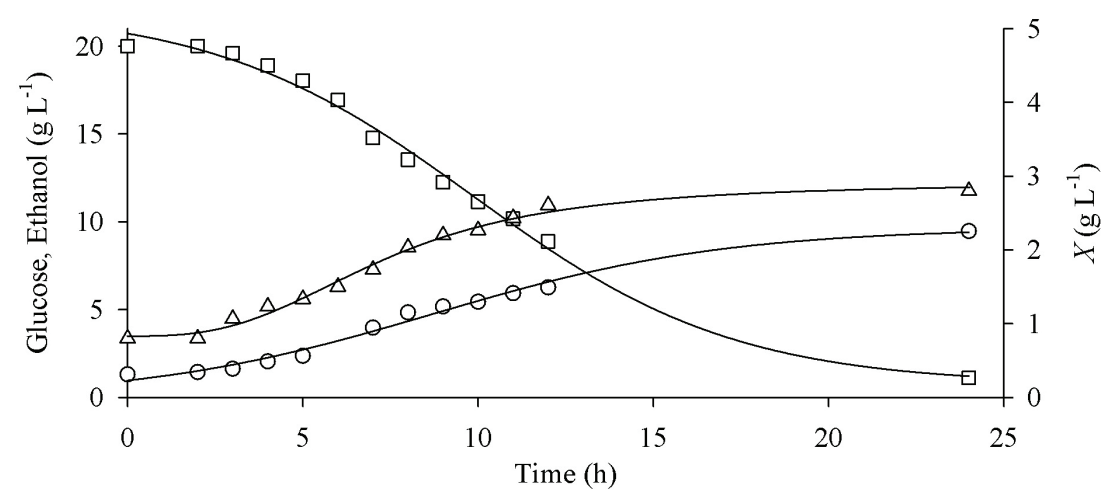

Fig. 3 - Changes in glucose $(\square)$, ethanol $(\mathrm{O})$, and biomass dry weight $(\triangle)$ concentrations during aerobic (a), and anaerobic (b) cultivation of genetically engineered $S$. cerevisiae on control media containing glucose in shake flasks

(a)

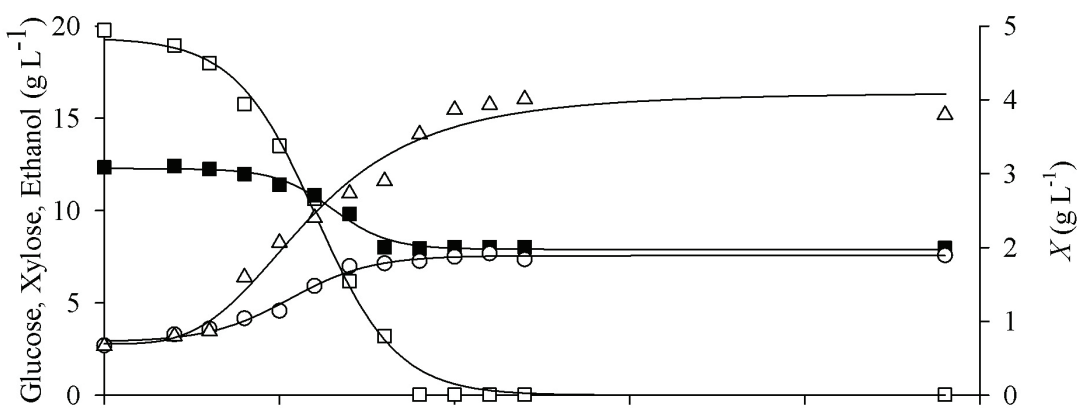

(b)

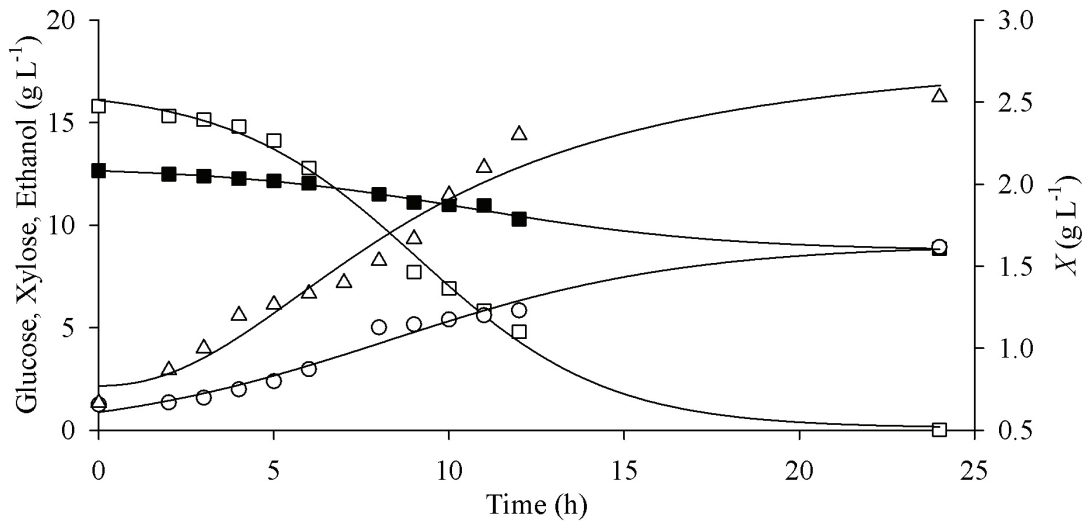

Fig. 4 - Changes in glucose ( $\square$ ), xylose (匹), ethanol (O), and cell number $(N, \triangle)$ concentrations during aerobic (a), and anaerobic cultivation (b) of genetically engineered $S$. cerevisiae on control media containing glucose and xylose in shake flasks

anaerobic $\left(0.21 \mathrm{~h}^{-1}\right)$ conditions due to the wellknown impact of oxygen on the microbial growth $^{31,32}$. Maximum biomass concentration in aerobic conditions was higher $\left(X_{\mathrm{m}}=4.18 \mathrm{~g} \mathrm{~L}^{-1}\right)$ in comparison to biomass concentration in anaerobic conditions $\left(X_{\mathrm{m}}=2.80 \mathrm{~g} \mathrm{~L}^{-1}\right)$. Also observed was that, even in aerobic conditions, this selected yeast strain was able to produce ethanol $\left(Y_{\mathrm{E}}=0.17 \mathrm{~g} \mathrm{~g}^{-1}\right.$, Ethanol content $\left.=3.47 \mathrm{~g} \mathrm{~L}^{-1}\right)$, while in anaerobic conditions $Y_{\mathrm{E}}$ was $0.42 \mathrm{~g} \mathrm{~g}^{-1}$ (Ethanol content $=8.16$ $\mathrm{g} \mathrm{L}^{-1}$ ), which is $82.35 \%$ of theoretical value ${ }^{31,32}$. 
Table 3 - Bioprocess efficiency parameters of the aerobic and anaerobic cultivation of genetically engineered yeast $S$. cerevisiae on different control media in shake flasks experiments

\begin{tabular}{c|c|c|c|c|c|c|c|c|c|c|c}
\hline $\begin{array}{c}\text { C source } \\
\text { in control } \\
\text { medium }\end{array}$ & Condition & $\begin{array}{c}t_{\text {lag }} \\
(\mathrm{h})\end{array}$ & $\begin{array}{c}t_{\text {exp }} \\
(\mathrm{h})\end{array}$ & $\begin{array}{c}r_{\text {glc }} \\
\left(\mathrm{h}^{-1}\right)\end{array}$ & $\begin{array}{c}r_{\mathrm{xyl}} \\
\left(\mathrm{h}^{-1}\right)\end{array}$ & $\begin{array}{c}\mu_{\mathrm{m}} \\
\left(\mathrm{h}^{-1}\right)\end{array}$ & $\begin{array}{c}X_{\mathrm{m}} \\
\left(\mathrm{g} \mathrm{L}^{-1}\right)\end{array}$ & $\begin{array}{c}r_{\mathrm{EtOH}} \\
\left(\mathrm{h}^{-1}\right)\end{array}$ & $\begin{array}{c}Y_{\mathrm{E}}^{*} \\
\left(\mathrm{~g} \mathrm{~g}^{-1}\right)\end{array}$ & $\begin{array}{c}E^{*} \\
(\%)\end{array}$ & $\begin{array}{c}\mathrm{VEP}^{*} \\
\left(\mathrm{~g} \mathrm{~L}^{-1} \mathrm{~h}^{-1}\right)\end{array}$ \\
\hline \multirow{2}{*}{ glucose } & $\begin{array}{c}\text { aerobic } \\
\text { anaerobic }\end{array}$ & 2 & 7 & 0.47 & - & 0.24 & 4.18 & 0.18 & 0.17 & 33.33 & 0.14 \\
\hline $\begin{array}{l}\text { glucose aerobic } \\
\text { and xylose anaerobic }\end{array}$ & 3 & 9 & 0.09 & - & 0.21 & 2.80 & 0.10 & 0.42 & 82.35 & 0.34 \\
\hline
\end{tabular}

$* Y_{\mathrm{E}}$, Ethanol yield, VEP; $E$ - Efficiency; VEP - Volumetric ethanol productivity

Growth of the $S$. cerevisiae strain in medium containing glucose and xylose is characterized by a slightly longer lag phase $\left(t_{\mathrm{lag}}=3 \mathrm{~h}\right.$ in aerobic and anaerobic conditions; Fig. 4a and Fig. 4b) compared to lag phase in medium containing only glucose $\left(t_{\text {las }}\right.$ $=2 \mathrm{~h}$ in aerobic and anaerobic conditions). All of the glucose from the medium was consumed in $7 \mathrm{~h}$ and $20 \mathrm{~h}$ in aerobic and anaerobic conditions, respectively. Xylose was simultaneously consumed from the medium with glucose until glucose was spent from the medium, and then xylose utilization decreased. Glucose consumption rate in aerobic conditions, in medium with glucose and xylose $\left(r_{\text {olc }}\right.$ $=0.48 \mathrm{~h}^{-1}$ ) was almost identical to the values obtained in medium containing only glucose $\left(r_{\text {glc }}=\right.$ $\left.0.47 \mathrm{~h}^{-1}\right)$. Xylose consumption rate in aerobic conditions was considerably lower than glucose consumption rate $\left(0.07 \mathrm{~h}^{-1}\right)$. In anaerobic conditions, xylose consumption rate was around $60 \%$ lower in comparison to aerobic cultivation $\left(0.03 \mathrm{~h}^{-1}\right.$; Table 3$)$.

Values for maximum specific growth rate in aerobic and anaerobic cultivations with glucose and xylose were $0.14 \mathrm{~h}^{-1}$ and $0.09 \mathrm{~h}^{-1}$, respectively. In these experiments, it was also observed that ethanol was produced in both aerobic and anaerobic conditions. Ethanol conversion coefficient $\left(Y_{\mathrm{E}}\right)$ in aerobic conditions in medium containing glucose and xylose was $0.20 \mathrm{~g} \mathrm{~g}^{-1}$ (Ethanol content $=4.88 \mathrm{~g} \mathrm{~L}^{-1}$ ), while in anaerobic conditions $0.39 \mathrm{~g} \mathrm{~g}^{-1}$ (Ethanol content $=7.68 \mathrm{~g} \mathrm{~L}^{-1}$ ), respectively. Bioprocess efficiency for aerobic conditions was $39.22 \%$ and for anaerobic conditions $76.47 \%$ (Table 3). Obtained results are comparable to data obtained by Lopes et $a l .{ }^{33}$ where glucose and xylose were simultaneously consumed by different genetically modified $S$. cerevisiae strains with ethanol conversion coefficient $\left(Y_{\mathrm{E}}\right)$ in the range of $0.34-0.45 \mathrm{~g} \mathrm{~g}^{-1}$.

\section{Anaerobic cultivations of genetically engineered S. cerevisiae on different liquor wheat straw hydrolysate media in shake flasks}

Pre-treatment of lignocellulosic raw materials, such as wheat straw, with dilute acid under high temperatures yields desirable products like mono- mer carbohydrates (glucose, xylose, arabinose) ${ }^{34}$, and a variety of undesirable products like organic acids and aromatic compounds (e.g., furfural, formic acid, hydroxymethylfurfural, levulinic acid, acetic acid ${ }^{7,24}$. Presence of inhibitory compounds can affect bioprocess efficiency depending on their concentration. Inhibitor compounds present in the liquor wheat straw hydrolysates used as a cultivation media for our research, are listed in Table 2. Concentration of compounds varied depending on pre-treatment conditions. Furfural and hydroxymethyl furfural are two most important inhibitors that are created in lignocellulosic biomass pre-treatment ${ }^{29,30}$. Influence of furans (furfural and hydroximethylfurfural) on the yeast growth and activity can be used as an inhibition indicator for other compounds present in the wheat straw hydrolysate also ${ }^{29,30}$. Modig et al. ${ }^{27}$ defined that furfural inhibits activity of alcohol dehydrogenase (ADH; EC 1.1.1.1), aldehyde dehydrogenase (ALDH; EC 1.2.1.5), and pyruvate dehydrogenase (PDH; EC 1.2.4.1). As already mentioned, temperature and residence time have significant impact on the furfural concentration in the pre-treated lignocellulosic biomass. In our research, the highest concentration of furfural was observed at $200{ }^{\circ} \mathrm{C}$ for pre-treatment with phosphoric acid as well as sulphuric acid (Table 2). It is well known that higher pre-treatment temperatures are related to higher furfural concentrations ${ }^{27,30}$, but prolongation of residence time decreases concentration of available furfural because of its degradation to levulinic and formic acid. The lowest furfural concentrations in our research were obtained at $160{ }^{\circ} \mathrm{C}$ and 1 minute residence time. Prolongation of residence time to 10 minutes, for example, decreased furfural concentration when compared to results obtained for 5-minute residence time at the same temperature, for both acids. Novak et $a l .{ }^{34}$ reported that $S$. cerevisiae yeast can grow and produce ethanol when cultivated on lignocellulosic biomass hydrolysate having furfural concentration up to $1 \mathrm{~g} \mathrm{~L}^{-1}$. Therefore, it was expected that furfural concentration would not greatly affect bioprocess efficiency during cultivation of genetically 
modified S. cerevisiae. Other inhibitory compounds, such as acetic, formic, and galacturonic acids are formed during degradation of hemicellulose in pre-treatments ${ }^{24,28,35-37}$. Weak acids influence intracellular anion concentration and accumulation ${ }^{36}$. They can easily diffuse through plasma membrane into yeast cell and decrease cytosolic $\mathrm{pH}$, which is then compensated by pumping protons out of the cell at the expense of ATP hydrolysis by the plasma membrane ATPase, and thus, less ATP is available for biomass formation ${ }^{36}$. Low levels of acetic, levulinic or formic acids can increase the ethanol yield, but ethanol yield decreases at higher concentrations ${ }^{37}$. Larsson et al. ${ }^{37}$ assume that low concentrations of weak acids can stimulate the production of ATP, as during anaerobic ethanol production. However, at higher concentrations of weak acids, the ATP demand would be so high that cells could not avoid acidification of the cytosol ${ }^{37}$, and therefore, inhibition of growth and ethanol production would occur. Acetic acid is known as an antimicrobial agent and as a strong inhibitor of yeast growth ${ }^{24,35}$. Casey et al. ${ }^{35}$ report that concentration of acetic acid higher than $1 \mathrm{~g} \mathrm{~L}^{-1}$ greatly influences xylose utilization by genetically modified $S$. cerevisiae yeast. Also, in literature ${ }^{35,37}$ it is stated that glucose consumption is not greatly influenced if concentration of acetic acid varies up to $7.5 \mathrm{~g} \mathrm{~L}^{-1}$. In our research, concentration of acetic acid in liquor wheat straw hydrolysates varied from $0.43 \mathrm{~g} \mathrm{~L}^{-1}$ to maximum $1.08 \mathrm{~g} \mathrm{~L}^{-1}$ (Table 2); therefore, greater inhibitory effect of acetic acid on growth and ethanol production was not expected. Maximal concentration of formic acid obtained with dilute acid pre-treatment of wheat straw was $1.49 \mathrm{~g} \mathrm{~L}^{-1}$ (at 200 ${ }^{\circ} \mathrm{C} / 10 \mathrm{~min} / 0.5 \% \mathrm{w} / \mathrm{w} \mathrm{H}_{2} \mathrm{SO}_{4}$ ), and the lowest 0.34 $\mathrm{g} \mathrm{L}^{-1}$ (at $160{ }^{\circ} \mathrm{C} / 5 \mathrm{~min} / 0.5 \% \mathrm{w} / \mathrm{w} \mathrm{H}_{2} \mathrm{SO}_{4}$ ), respectively. Concentration range is below reported concentrations that have inhibitory effect ${ }^{37}$. Inhibition of growth and ethanol production with chemical compounds obtained during pre-treatment of lignocellulosic biomass must be considered with care. Although it is well known how individual compounds influence bioprocess efficiency ${ }^{37,38}$ of ethanol production, cumulative effect of more than one inhibitor in complex media such as wheat straw hydrolysate is still greatly researched in order to increase ethanol yield and carbohydrates utilization $^{36,39}$.

In our research, selected strain of modified $S$. cerevisiae has capability of growth and ethanol production in nutrient-rich media containing xylose and glucose (Fig. 4). After experiments performed in those media, the strains were tested for their ability to grow and produce ethanol in wheat straw hydrolysate containing glucose and xylose as main carbon and energy sources. Total acids (acetic, for- mic, levulinic) and furfural concentration in our liquor wheat straw hydrolysate media are below reported concentrations that inhibit growth and ethanol production ${ }^{38}$. This is proof that our pre-treatment process with dilute acids at higher temperatures in the HPR is efficient regarding the low concentrations of formed inhibitors. Removal of inhibitory compounds from complex cultivation media is time-consuming, cost-intensive, and has relatively high energy demands ${ }^{36}$. The optimization of pre-treatment in the HPR is an important step in the development of a sustainable process of waste lignocellulosic biomass utilization for biofuels or biochemicals production. Wheat straw hydrolysates obtained by dilute acid pre-treatment at different temperatures $\left(160-200{ }^{\circ} \mathrm{C}\right)$ and 10 minutes residence time were used for further cultivation, because they contain the highest amount of carbohydrates. The wheat straw hydrolysate media were supplemented only by yeast extract, ammonium hydrogen phosphate, and ammonium sulphate as a source of other nutrients and minerals for yeast growth. Anaerobic cultivations of genetically engineered $S$. cerevisiae yeast were performed in Erlenmeyer flasks inoculated with $10 \%(\mathrm{v} / \mathrm{v})$ inoculum grown overnight at $25{ }^{\circ} \mathrm{C}$ and without $\mathrm{pH}$ control.

Alteration of glucose, xylose, ethanol, and yeast cells number (CFU $\left.\mathrm{mL}^{-1}\right)$ concentrations during $S$. cerevisiae cultivation on wheat straw hydrolysate media obtained with sulphuric acid $(0.5 \%$ $\left.\mathrm{w} / \mathrm{w} \mathrm{H}_{2} \mathrm{SO}_{4}\right)$ and phosphoric acid $(2.0 \% \mathrm{w} / \mathrm{w}$ $\left.\mathrm{H}_{3} \mathrm{PO}_{4}\right)$ in pre-treatment are presented in Figs. 5 and 6 , respectively. Other compounds like arabinose, acetic acid, formic acid, levulinic acid, and glycerol were also determined, but not presented. The main reason is that the concentrations of these compounds were almost constant during cultivations ${ }^{34}$. Bioprocess efficiency parameters obtained during $S$. cerevisiae cultivations on the liquor wheat straw hydrolysate media are presented in Table 4. As may be seen in Table 4, lag phase time of our yeast strain $\left(t_{\mathrm{lag}}=2 \mathrm{~h}\right)$ was not significantly affected by the different composition of liquor wheat straw hydrolysate obtained at different temperatures $\left(160-200{ }^{\circ} \mathrm{C}\right)$ and same residence time (10 minutes) for both pre-treatment processes. Also, exponential growth time is the same for all cases $(3 \mathrm{~h})$, except when grown at $200{ }^{\circ} \mathrm{C} / 10 \mathrm{~min} / 2.0 \% \mathrm{w} / \mathrm{w} \mathrm{H}_{3} \mathrm{PO}_{4}$ where exponential time is slightly longer $(4 \mathrm{~h})$. Although there is no significant difference in $t_{\text {lag }}$ and $t_{\text {exp }}$ when cultivation is carried out on different liquor wheat straw hydrolysate media, growth rate varies. During anaerobic fermentation on liquor wheat straw hydrolysate media obtained by sulphuric acid pre-treatment, growth rate was $\mu=0.23 \mathrm{~h}^{-1}$ for $160{ }^{\circ} \mathrm{C} / 10$ $\min , \mu=0.25 \mathrm{~h}^{-1}$ for $180^{\circ} \mathrm{C} / 10 \mathrm{~min}$, and $\mu=0.22 \mathrm{~h}^{-1}$ for $200{ }^{\circ} \mathrm{C} / 10 \mathrm{~min}$, respectively. During anaerobic 
cultivation on liquor wheat straw hydrolysate media obtained by phosphoric acid pre-treatment, slightly lower growth rates $\left(\mu_{\mathrm{m}}=0.19 \mathrm{~h}^{-1}\right.$ for $160{ }^{\circ} \mathrm{C} / 10 \mathrm{~min}$, $\mu_{\mathrm{m}}=0.19 \mathrm{~h}^{-1}$ for $180^{\circ} \mathrm{C} / 10 \mathrm{~min}, \mu_{\mathrm{m}}=0.21 \mathrm{~h}^{-1}$ for $200{ }^{\circ} \mathrm{C} / 10 \mathrm{~min}$ ) were observed. Utilization of glucose and xylose depends on composition of liquor wheat straw hydrolysate. All the glucose was consumed in $10 \mathrm{~h}$, with glucose consumption rate of $0.33 \mathrm{~h}^{-1}$ (Table 4) for cultivation on liquor wheat straw hydrolysate media obtained at $160{ }^{\circ} \mathrm{C} / 10 \mathrm{~min} /$ $0.5 \% \mathrm{w} / \mathrm{W} \mathrm{H}_{2} \mathrm{SO}_{4}$. For cultivation on liquor hydrolysate media $180{ }^{\circ} \mathrm{C} / 10 \mathrm{~min} / 0.5 \% \mathrm{w} / \mathrm{w} \mathrm{H}_{2} \mathrm{SO}_{4}$ and $200{ }^{\circ} \mathrm{C} / 10 \mathrm{~min} / 0.5 \% \mathrm{w} / \mathrm{w} \mathrm{H}_{2} \mathrm{SO}_{4}$ glucose consumption rate $\left(r_{\text {glc }}=0.58 \mathrm{~h}^{-1}\right)$ increased by $43 \%$ compared to the previous experiment, and consequently, glucose was completely consumed in 5 hours. Xylose consumption was much slower than that of glucose, and it decreased with the increase in inhibitor compound concentrations that are correlated with the increase in pre-treatment temperature (Table 2). This observation is in accordance with literature data $^{35}$. For $S$. cerevisiae cultivations on liquor wheat straw hydrolysate media, the obtained xylose consumption rate had a declining trend; at $160{ }^{\circ} \mathrm{C} / 10$ $\mathrm{min} / 0.5 \% \mathrm{w} / \mathrm{w} \mathrm{H}_{2} \mathrm{SO}_{4}$, xylose consumption rate was $0.05 \mathrm{~h}^{-1}$, at $180^{\circ} \mathrm{C} / 10 \mathrm{~min} / 0.5 \% \mathrm{w} / \mathrm{w} \mathrm{H}_{2} \mathrm{SO}_{4}$ $0.04 \mathrm{~h}^{-1}$, and at $200{ }^{\circ} \mathrm{C} / 10 \mathrm{~min} / 0.5 \% \mathrm{w} / \mathrm{w} \mathrm{H}_{2} \mathrm{SO}_{4}$ $0.02 \mathrm{~h}^{-1}$, respectively.

When fermentation was carried out on liquor wheat straw hydrolysate media obtained with phosphoric acid pre-treatment, glucose was completely consumed in 5 hours for hydrolysates obtained at $160{ }^{\circ} \mathrm{C} / 10 \mathrm{~min}$ and $180{ }^{\circ} \mathrm{C} / 10 \mathrm{~min}$, with glucose consumption rate of $0.41 \mathrm{~h}^{-1}$ and $0.38 \mathrm{~h}^{-1}$, respectively. An exception was cultivation in liquor wheat straw hydrolysate obtained at $200{ }^{\circ} \mathrm{C} / 10 \mathrm{~min} / 2.0 \%$ w/w $\mathrm{H}_{3} \mathrm{PO}_{4}$, where low glucose consumption rate was determined $\left(r_{\text {glc }}=0.05 \mathrm{~h}^{-1}\right)$, and even after $24 \mathrm{~h}$ of fermentation, glucose was still present in the medium. The probable cause for this occurrence is synergistic influence of media composition and combined effect of inhibitory compounds on bioprocess efficiency (Table 4). Xylose consumption rate was $0.03 \mathrm{~h}^{-1}$ in media obtained at $160{ }^{\circ} \mathrm{C} / 10$ min, $0.02 \mathrm{~h}^{-1}$ in media obtained at $180{ }^{\circ} \mathrm{C} / 10 \mathrm{~min}$, and at $200{ }^{\circ} \mathrm{C} / 10 \mathrm{~min}$, respectively. In all experiments where genetically modified $S$. cerevisae yeast was cultivated in media containing liquor wheat straw hydrolysates obtained with either dilute sulphuric acid or phosphoric acid, it can be observed that there was no xylose consumption when glucose was depleted from the media. The same phenomenon was also observed in cultivations on nutrient-rich media containing glucose and xylose as carbon sources.

Ethanol production and bioprocess efficiency depends on microorganism used, availability of fer- menting carbohydrates and other nutrients, concentration of inhibition compounds, process parameters such as temperature, mixing, aeration, $\mathrm{pH}$ control, cultivation technique, and general process control. Complex media such as liquor wheat straw hydrolysates (obtained with dilute acid pre-treatment in HPR) with available fermentable carbohydrates and inhibition compounds represents a great challenge for yeast metabolism and ethanol production. Although, in terms of development of sustainable bioprocesses for biofuels production, the usage of waste and residual lignocellulose raw materials presents a significant source of fermentable carbohydrates, but obtaining them is not an easy task. During pre-treatment in HPR, xylose concentration was two to three times higher than glucose concentration. Since not many strains of $S$. cerevisiae yeast are able to utilize xylose as a sole carbon source, one of the solutions is either optimisation of the pre-treatment process in order to obtain higher yields of glucose or the usage of genetically modified yeast capable of xylose consumption. Our pre-treatment was directed at reducing the inhibitory compounds in wheat straw hydrolysates obtained after dilute acid pre-treatment, so that the selected genetically modified yeast strain would not be greatly inhibited during growth and ethanol production. As may be seen in Table 2, available glucose and xylose concentration increases with increase in pre-treatment temperature. Accordingly, ethanol production rate increases from $0.1 \mathrm{~h}^{-1}$ for $160{ }^{\circ} \mathrm{C} /$ $10 \mathrm{~min} / 0.5 \% \mathrm{w} / \mathrm{w} \mathrm{H}_{2} \mathrm{SO}_{4}$ to 0.12 for $180{ }^{\circ} \mathrm{C} / 10$ $\mathrm{min} / 0.5 \% \mathrm{w} / \mathrm{w} \mathrm{H}_{2} \mathrm{SO}_{4}$ and $200{ }^{\circ} \mathrm{C} / 10 \mathrm{~min} / 0.5 \%$ w/w $\mathrm{H}_{2} \mathrm{SO}_{4}$. Maximal ethanol conversion coefficient was determined for cultivation on the hydrolysate obtained at $180{ }^{\circ} \mathrm{C} / 10 \mathrm{~min} / 0.5 \% \mathrm{w} / \mathrm{w} \mathrm{H}_{2} \mathrm{SO}_{4}$ $\left(Y_{\mathrm{E}}=0.25 \mathrm{~g} \mathrm{~g}^{-1}\right.$; Ethanol content $\left.=1.09 \mathrm{~g} \mathrm{~L}^{-1}\right)$ with $^{4}$ bioprocess efficiency of $49.02 \%$. Cultivation on the liquor hydrolysate obtained at $160{ }^{\circ} \mathrm{C} / 10 \mathrm{~min} / 0.5 \%$ $\mathrm{w} / \mathrm{w} \mathrm{H}_{2} \mathrm{SO}_{4}$ was $60 \%$ lower in comparison $\left(Y_{\mathrm{E}}=\right.$ $0.1 \mathrm{~g} \mathrm{~g} \mathrm{~g}^{-1}$; Ethanol content $\left.=0.63 \mathrm{~g} \mathrm{~L}^{-1}\right)$. For the same cultivation, ethanol efficiency and productivity also decreased. Cultivation on liquor hydrolysate obtained at $200{ }^{\circ} \mathrm{C} / 10 \mathrm{~min} / 0.5 \%$ w/w $\mathrm{H}_{2} \mathrm{SO}_{4}$ had only $12 \%$ decrease in ethanol production rate when compared to cultivation on liquor wheat straw hydrolysate obtained at $180{ }^{\circ} \mathrm{C} / 10 \mathrm{~min} / 0.5 \% \mathrm{w} / \mathrm{w}$ $\mathrm{H}_{2} \mathrm{SO}_{4}$ with the same ethanol productivity (VEP = $0.05 \mathrm{~g} \mathrm{~L}^{-1} \mathrm{~h}^{-1}$ ) and similar bioprocess efficiency $(43.14 \%)$. Although cultivations on liquor hydrolysate obtained at $180{ }^{\circ} \mathrm{C}$ and $200{ }^{\circ} \mathrm{C}$ with $10 \mathrm{~min}$ residence time and $0.5 \% \mathrm{w} / \mathrm{w}_{2} \mathrm{SO}_{4}$ have approximately the same concentrations of available glucose and xylose (Fig. 5), the difference is in concentrations of inhibitory compounds (Table 2) such as furfural, acetic acid and formic acid, and their probable influence on bioprocess efficiency. For cultiva- 
(a)

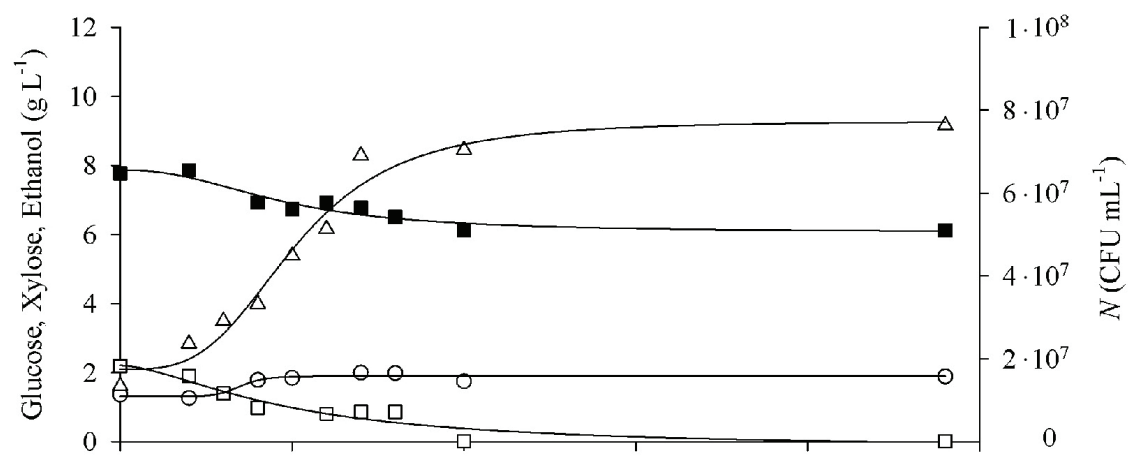

(b)

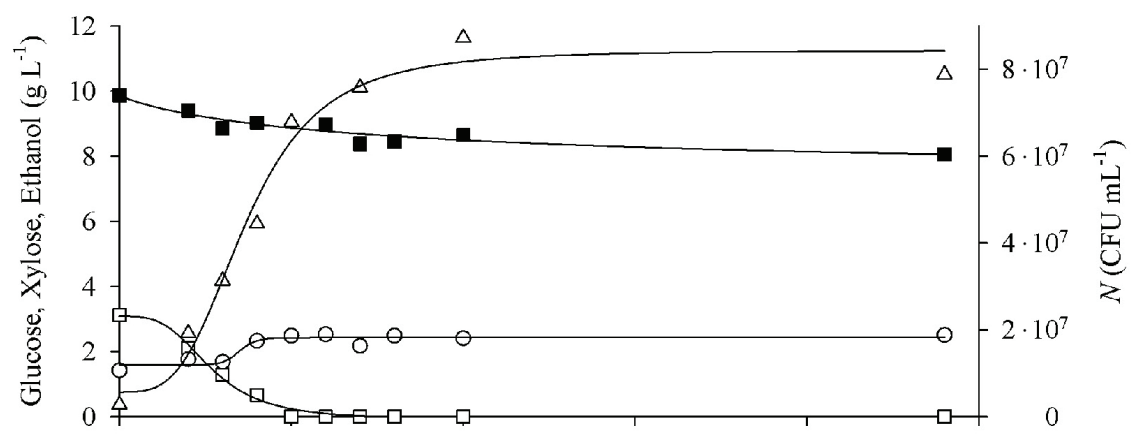

(c)

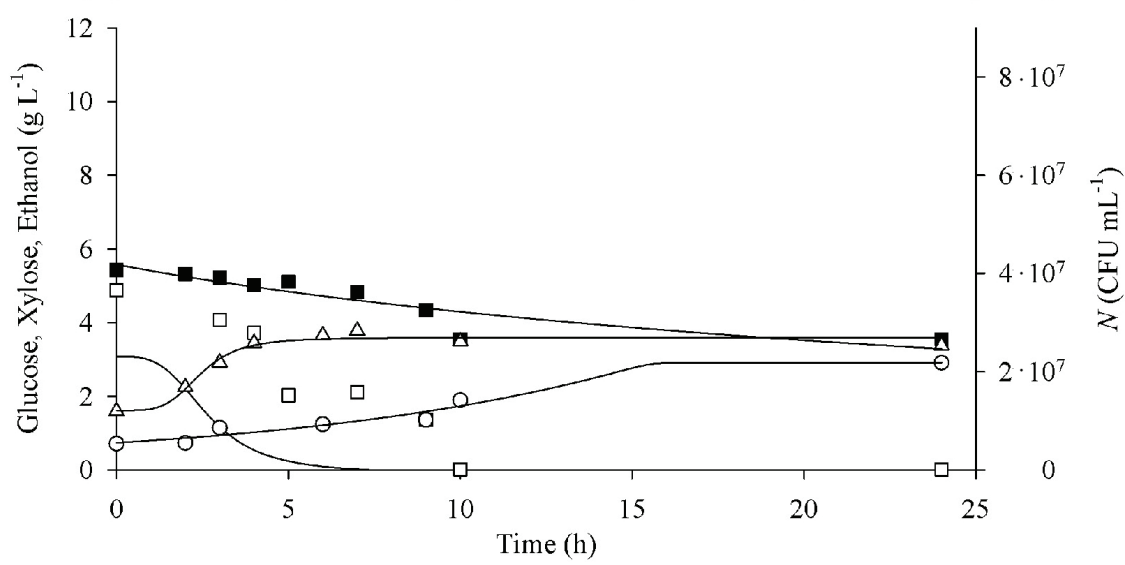

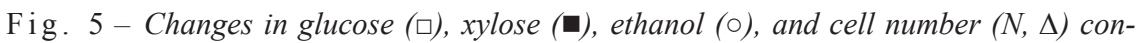
centrations during anaerobic cultivation of genetically engineered $S$. cerevisiae on different liquor wheat straw hydrolysates: $160 \quad{ }^{\circ} \mathrm{C} / 10 \quad \mathrm{~min} / 0.5 \quad \% \quad \mathrm{w} / \mathrm{w} \quad \mathrm{H}_{2} \mathrm{SO}_{4}(\mathrm{a})$; $180{ }^{\circ} \mathrm{C} / 10 \mathrm{~min} / 0.5 \% \mathrm{w} / \mathrm{w} \mathrm{H}_{2} \mathrm{SO}_{4}(\mathrm{~b}) ; 200{ }^{\circ} \mathrm{C} / 10 \mathrm{~min} / 0.5 \% \mathrm{w} / \mathrm{w} \mathrm{H}_{2} \mathrm{SO}_{4}$ (c) in shake flasks

tion on liquor wheat straw hydrolysate obtained at $160{ }^{\circ} \mathrm{C} / 10 \mathrm{~min} / 2.0 \% \mathrm{w} / \mathrm{w} \mathrm{H}_{3} \mathrm{PO}_{4}$, the ethanol production rate $\left(r_{\mathrm{E}}\right)$ was $0.18 \mathrm{~h}^{-1}(80 \%$ increase when compared to cultivation on liquor hydrolysate obtained at $160{ }^{\circ} \mathrm{C} / 10 \mathrm{~min} / 0.5 \% \mathrm{w} / \mathrm{w}_{2} \mathrm{SO}_{4}$ ) with ethanol content of $1.58 \mathrm{~g} \mathrm{~L}^{-1}$, ethanol conversion coefficient of $0.29 \mathrm{~g} \mathrm{~g}^{-1}$, efficiency of $56.82 \%$, and productivity of $0.07 \mathrm{~g} \mathrm{~L}^{-1} \mathrm{~h}^{-1}$. With increase in concentration of inhibitory compounds in the cultivation media that are proportional to temperature increase, ethanol production rate decreases accordingly (Table 3 and Table 4). It was calculated that $66 \%$ decrease in $r_{\mathrm{E}}$ was observed when results for pre-treatment at $160{ }^{\circ} \mathrm{C} / 10 \mathrm{~min} / 2.0 \% \mathrm{w} / \mathrm{w} \mathrm{H}_{3} \mathrm{PO}_{4}$ and at $200{ }^{\circ} \mathrm{C} / 10 \mathrm{~min} / 2.0 \% \mathrm{w} / \mathrm{w} \quad \mathrm{H}_{3} \mathrm{PO}_{4}$ were compared. Accordingly, VEP decreases from
$0.07 \mathrm{~g} \mathrm{~L}^{-1} \mathrm{~h}^{-1}$ at $160{ }^{\circ} \mathrm{C}$ to $0.04 \mathrm{~g} \mathrm{~L}^{-1} \mathrm{~h}^{-1}$ at $180{ }^{\circ} \mathrm{C}$, and finally to $0.03 \mathrm{~g} \mathrm{~L}^{-1} \mathrm{~h}^{-1}$ at $200{ }^{\circ} \mathrm{C}$ (Table 4). Ethanol conversion coefficients $\left(Y_{\mathrm{E}}\right)$, when compared to the cultivations on liquor wheat straw hydrolysates obtained with $0.5 \% \mathrm{w} / \mathrm{w}_{2} \mathrm{SO}_{4}$, were slightly higher. Maximal ethanol conversion coefficient $\left(Y_{\mathrm{E}}=0.46 \mathrm{~g} \mathrm{~g}^{-1}\right.$; Ethanol content $\left.=1.46 \mathrm{~g} \mathrm{~L}^{-1}\right)$ and bioprocess efficiency $(E=90.19 \%)$ were observed for cultivation on liquor wheat straw hydrolysate obtained at $160{ }^{\circ} \mathrm{C} / 10 \mathrm{~min} / 2.0 \% \mathrm{w} / \mathrm{w} \mathrm{H}_{3} \mathrm{PO}_{4}$, and they are comparable to results obtained by Lopes et al. ${ }^{33}$ Ethanol conversion coefficients for cultivation on liquor wheat straw hydrolysates obtained at $180{ }^{\circ} \mathrm{C} / 10 \mathrm{~min}$ and at $200{ }^{\circ} \mathrm{C} / 10 \mathrm{~min}$ were $0.49 \mathrm{~g} \mathrm{~g}^{-1}$ (Ethanol content $=0.96 \mathrm{~g} \mathrm{~L}^{-1}$ ) and $0.27 \mathrm{~g} \mathrm{~g}^{-1}$ (Ethanol content $=0.82 \mathrm{~g} \mathrm{~L}^{-1}$ ), respectively. 
(a)

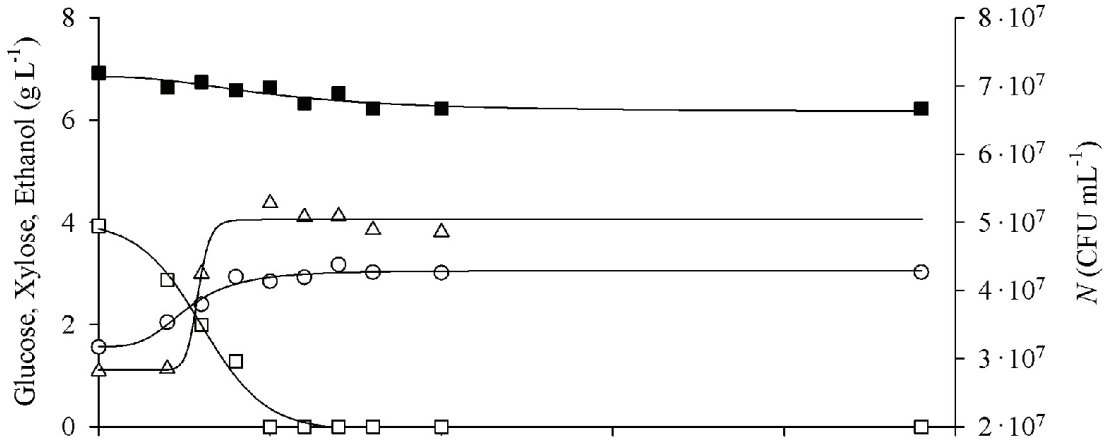

(b)

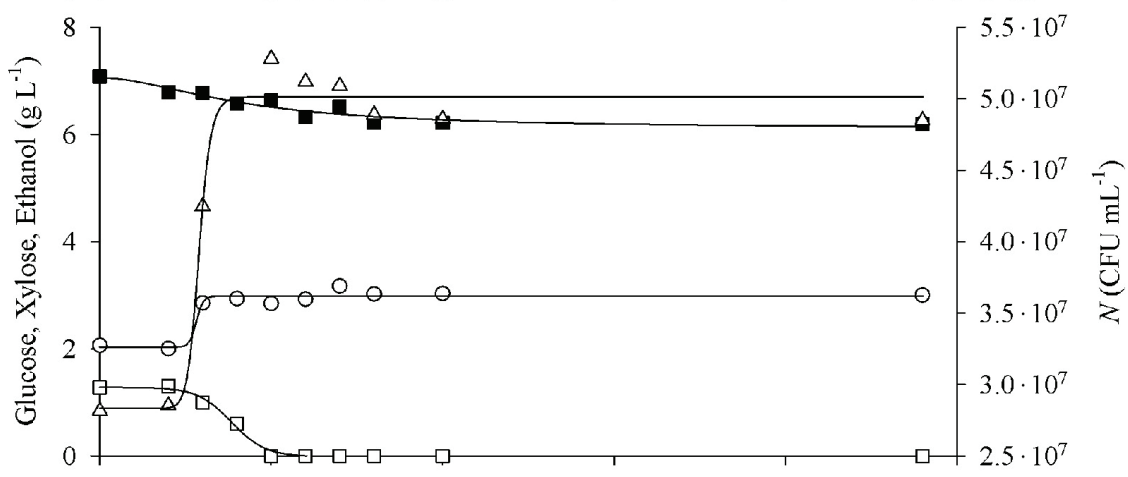

(c)

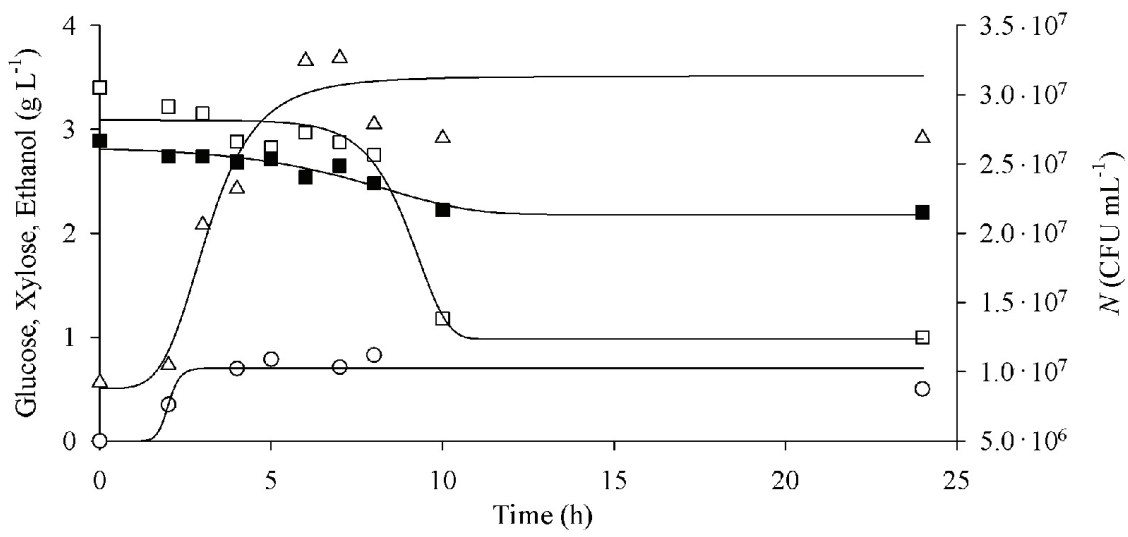

Fig. 6 - Changes in glucose ( $\square$ ), xylose (ロ), ethanol (O), and cell number (N, $\Delta$ ) concentrations during anaerobic cultivation of genetically engineered $S$. cerevisiae on different liquor wheat straw hydrolysate media: $160{ }^{\circ} \mathrm{C} / 10 \mathrm{~min} / 2 \% \mathrm{w} / \mathrm{w} \mathrm{H} \mathrm{HO}_{4}$ (a); wheat straw $/ 180{ }^{\circ} \mathrm{C} / 10 \mathrm{~min} / 2.0 \% \mathrm{w} / \mathrm{w} \mathrm{H}_{3} \mathrm{PO}_{4}\left(\right.$ b) $; 200{ }^{\circ} \mathrm{C} / 10 \mathrm{~min} / 2.0 \% \mathrm{w} / \mathrm{w} \mathrm{H}_{3} \mathrm{PO}_{4}$ (c) in shake flasks

\section{Anaerobic cultivations of genetically engineered S. cerevisiae on different liquor wheat straw hydrolysate media in HRTB}

Development of sustainable bioprocesses for biofuels production requires optimisation of energy consumption, as well as economic and ecological usage of raw materials. Currently, lignocellulosic raw materials have the advantage of being inexpensive sources of fermentable sugars ${ }^{40}$. Availability of sugars in lignocellulosic raw materials, such as wheat straw, greatly depends on used pre-treatment process. Using weak acids for treatment of raw lignocellulosic materials is one of the solutions for reducing toxic compounds and residual waste after pre-treatment process. Also, after such treatment, solid waste (wheat straw that is not hydrolysed) can be used in further process as a semi-solid/solid substrate for cultivation of molds, yeasts or bacteria ${ }^{41,42}$, and production of biochemicals. Another solution is to use solid part after weak acid pre-treatment as a substrate for enzymatic treatment with cellulases in order to increase total carbohydrates content and availability of fermentable sugars.

Apart from optimisation of the pre-treatment process, optimisation of the cultivation technique is also necessary. Bioreactor design has an important role in bioprocess efficiency, as it influences bioprocess kinetics, hydrodynamics, and scale of operation $^{43}$. A wild strain of $S$. cerevisiae on a semi-solid substrate (sugar beet cossettes) for bioethanol production was cultivated in the HRTB ${ }^{19}$. Therefore, this type of bioreactor was chosen for bioethanol 


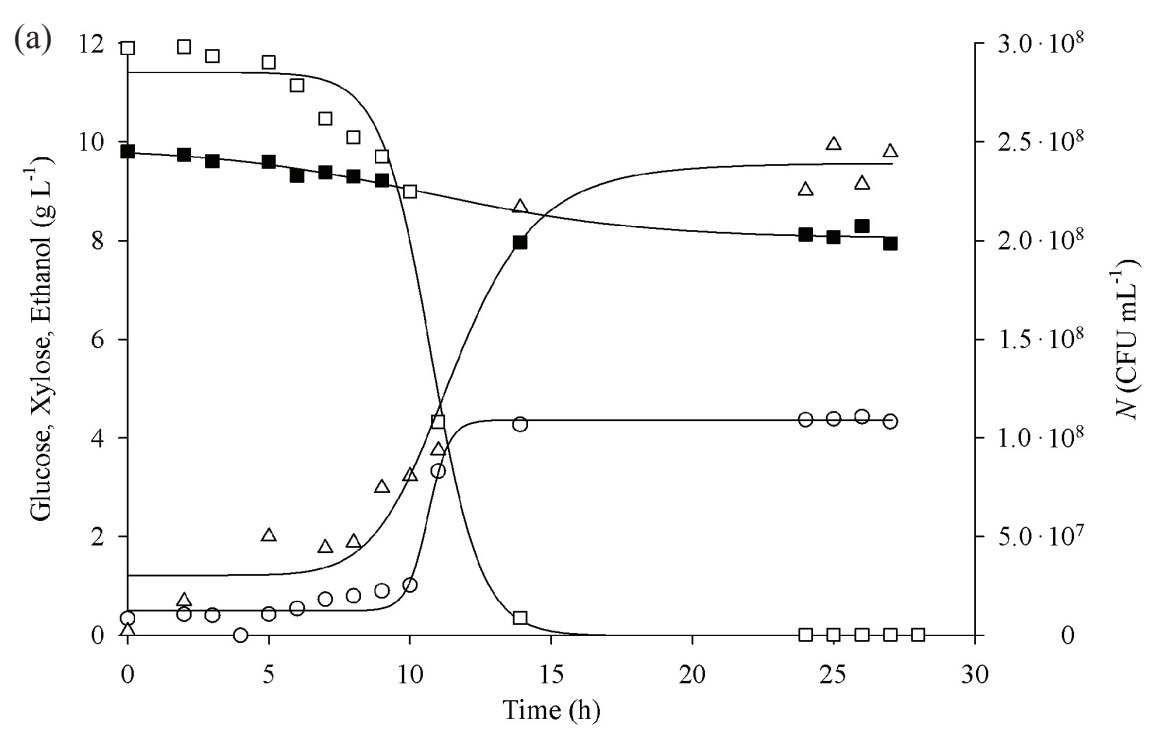

Fig. 7 - Changes in glucose (口), xylose (®), ethanol (O), and cell number (N, $\Delta)$ concentrations during anaerobic cultivation of genetically engineered $S$. cerevisiae on liquor wheat straw hydrolysate media obtained at $180{ }^{\circ} \mathrm{C} / 5 \mathrm{~min} / 0.5 \% \mathrm{w} / \mathrm{w} \mathrm{H}_{2} \mathrm{SO}_{4}$ in the HRTB

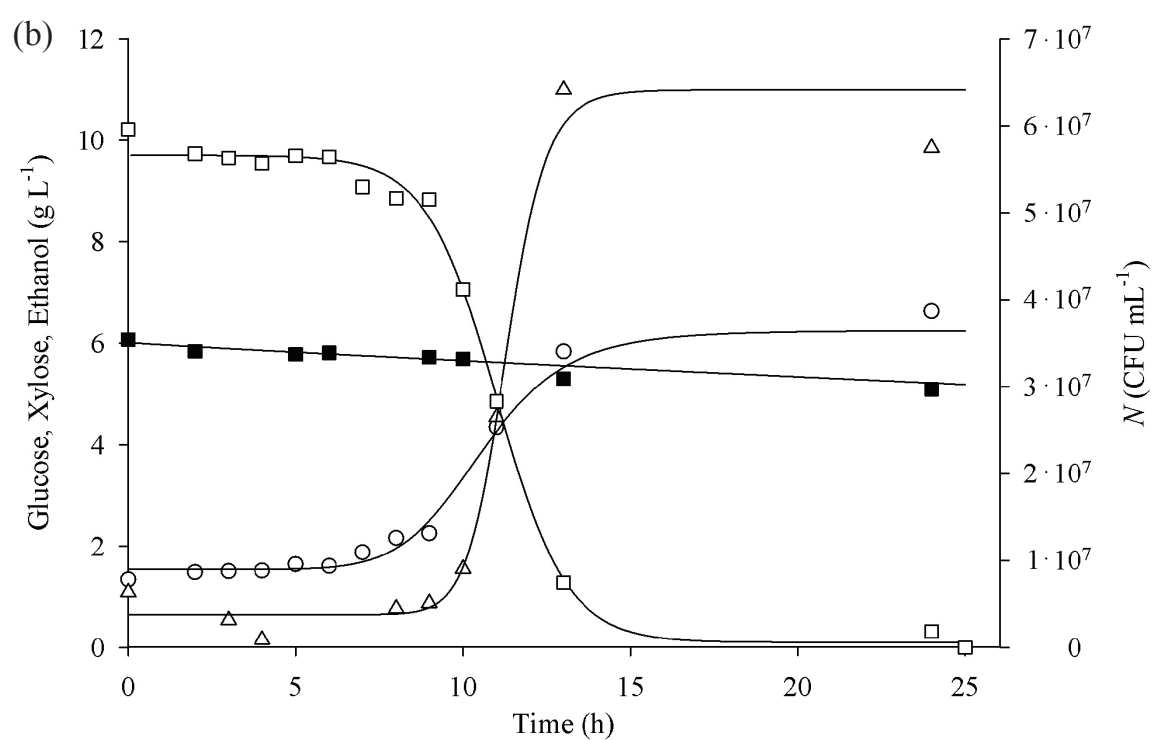

Fig. 8 - Changes in glucose ( $\square$ ), xylose (ロ), ethanol (O), and cell number (N, $\Delta$ ) concentrations during anaerobic cultivation of genetically engineered $S$. cerevisiae on liquor wheat straw hydrolysate media obtained at $180^{\circ} \mathrm{C} / 5 \mathrm{~min} / 2.0 \% \mathrm{w} / \mathrm{w} \mathrm{H}_{3} \mathrm{PO}_{4}$ in the HRTB

production with genetically modified strain of $S$. cerevisiae on the wheat straw hydrolysates. In previous research ${ }^{19}$, the optimal combination of HRTB process parameters for bioethanol production was also determined. This HRTB combination of process parameters (12 minutes of HRTB rotation at 20 $\mathrm{min}^{-1}$ and 48 minutes of HRTB stagnation in a onehour period) was selected to be additionally evaluated. As it was proven during cultivations in shake flasks (in either nutrient-rich or liquor wheat straw hydrolysates media), xylose utilization decreased when glucose was not present in the media. To enhance xylose consumption during cultivation in
HRTB, glucose $\left(10 \mathrm{~g} \mathrm{~L}^{-1}\right)$ was added to liquor wheat straw hydrolysates cultivation media. Cultivation in shake flasks has proven that our selected genetically modified strain can grow and produce ethanol in media containing glucose and xylose as a carbon source (Table 4, Figs. 5-6). It was therefore interesting to study ethanol production on liquor wheat straw hydrolysates in larger volume $(5 \mathrm{~L}$ in the HRTB). Liquor wheat straw hydrolysates used for cultivation were obtained at $180{ }^{\circ} \mathrm{C}$ and residence time of 10 minutes for both sulphuric acid and phosphoric acid, because they had the highest total fermentable sugars content (Table 2). Results of 
Table 4 -Bioprocess efficiency parameters of the anaerobic cultivation of S. cerevisiae yeast on the liquor wheat straw hydrolysate media in shake flasks and HRTB

\begin{tabular}{|c|c|c|c|c|c|c|c|c|c|c|}
\hline & Wheat straw hydrolysate medium & $\begin{array}{l}t_{\text {lag }} \\
(\mathrm{h})\end{array}$ & $\begin{array}{l}t_{\text {exp }} \\
(\mathrm{h})\end{array}$ & $\begin{array}{c}r_{\text {glc }} \\
\left(\mathrm{h}^{-1}\right)\end{array}$ & $\begin{array}{c}r_{\mathrm{xyl}} \\
\left(\mathrm{h}^{-1}\right)\end{array}$ & $\begin{array}{c}\mu_{\mathrm{m}} \\
\left(\mathrm{h}^{-1}\right)\end{array}$ & $\begin{array}{l}r_{\mathrm{EtOH}} \\
\left(\mathrm{h}^{-1}\right)\end{array}$ & $\begin{array}{c}Y_{\mathrm{E}}^{*} \\
\left(\mathrm{~g} \mathrm{~g}^{-1}\right)\end{array}$ & $\begin{array}{c}E^{*} \\
(\%)\end{array}$ & $\begin{array}{c}\mathrm{VEP}^{*} \\
\left(\mathrm{~g} \mathrm{~L}^{-1} \mathrm{~h}^{-1}\right)\end{array}$ \\
\hline \multirow{6}{*}{ 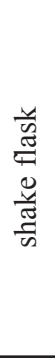 } & $160{ }^{\circ} \mathrm{C} / 10 \mathrm{~min} / 0.5 \% \mathrm{w} / \mathrm{w} \mathrm{H}_{2} \mathrm{SO}_{4}$ & 2 & 3 & 0.33 & 0.05 & 0.23 & 0.10 & 0.10 & 19.61 & 0.02 \\
\hline & $180{ }^{\circ} \mathrm{C} / 10 \mathrm{~min} / 0.5 \% \mathrm{w} / \mathrm{w} \mathrm{H}_{2} \mathrm{SO}_{4}$ & 2 & 3 & 0.58 & 0.04 & 0.25 & 0.12 & 0.25 & 49.02 & 0.05 \\
\hline & $200{ }^{\circ} \mathrm{C} / 10 \mathrm{~min} / 0.5 \% \mathrm{w} / \mathrm{w} \mathrm{H}_{2} \mathrm{SO}_{4}$ & 2 & 3 & 0.58 & 0.02 & 0.22 & 0.12 & 0.22 & 43.14 & 0.05 \\
\hline & $160{ }^{\circ} \mathrm{C} / 10 \mathrm{~min} / 2.0 \% \mathrm{w} / \mathrm{w} \mathrm{H}_{3} \mathrm{PO}_{4}$ & 2 & 3 & 0.41 & 0.03 & 0.19 & 0.18 & 0.29 & 56.86 & 0.07 \\
\hline & $180{ }^{\circ} \mathrm{C} / 10 \mathrm{~min} / 2.0 \% \mathrm{w} / \mathrm{w} \mathrm{H}_{3} \mathrm{PO}_{4}$ & 2 & 3 & 0.38 & 0.02 & 0.19 & 0.09 & 0.38 & 74.51 & 0.04 \\
\hline & $200{ }^{\circ} \mathrm{C} / 10 \mathrm{~min} / 2.0 \% \mathrm{w} / \mathrm{w} \mathrm{H}_{3} \mathrm{PO}_{4}$ & 2 & 4 & 0.05 & 0.02 & 0.21 & 0.06 & 0.23 & 45.10 & 0.03 \\
\hline \multirow{2}{*}{$\begin{array}{l}\stackrel{p}{\underline{\underline{y}}} \\
\text { 采 }\end{array}$} & $180{ }^{\circ} \mathrm{C} / 10 \mathrm{~min} / 0.5 \% \mathrm{w} / \mathrm{w} \mathrm{H}_{2} \mathrm{SO}_{4}$ & 5 & 8 & 0.22 & 0.01 & 0.22 & 0.14 & 0.30 & 58.82 & 0.15 \\
\hline & $180{ }^{\circ} \mathrm{C} / 10 \mathrm{~min} / 2.0 \% \mathrm{w} / \mathrm{w} \mathrm{H}_{3} \mathrm{PO}_{4}$ & 9 & 14 & 0.49 & 0.01 & 0.58 & 0.24 & 0.45 & 88.24 & 0.22 \\
\hline
\end{tabular}

$* Y_{\mathrm{E}}$, Ethanol yield, VEP; $E$ - Efficiency; VEP - Volumetric ethanol productivity

these cultivations are presented in Figs. 7-8 and Table 4. As may be seen from the results, $t_{\text {lag }}$ and $t_{\mathrm{exp}}$ significantly increased compared to cultivations in shake flasks (Table 4). For cultivation in media obtained with pre-treatment at $180{ }^{\circ} \mathrm{C} / 10 \mathrm{~min} / 0.5 \%$ $\mathrm{w} / \mathrm{w} \mathrm{H}_{2} \mathrm{SO}_{4}, t_{\mathrm{lag}}$ is 5 hours and almost double that $(9$ hours) for cultivation on medium obtained at 180 ${ }^{\circ} \mathrm{C} / 10 \mathrm{~min} / 2.0 \% \mathrm{w} / \mathrm{w} \mathrm{H}_{3} \mathrm{PO}_{4}$. Accordingly, $t_{\text {exp }}$ increased to $8 \mathrm{~h}$ for sulphuric acid liquor wheat straw hydrolysates as a cultivation medium, and 14 hours for phosphoric acid wheat straw hydrolysates, respectively. Growth rate on liquor hydrolysates obtained with sulphuric acid was $0.22 \mathrm{~h}^{-1}$, and $0.58 \mathrm{~h}^{-1}$ for cultivation on liquor hydrolysate obtained with phosphoric acid (Figs. 7 and 8; Table 4). Determined glucose consumption rate was $0.22 \mathrm{~h}^{-1}$ for cultivation on liquor hydrolysates obtained at 180 ${ }^{\circ} \mathrm{C} / 10 \mathrm{~min} / 0.5 \% \mathrm{w} / \mathrm{w} \mathrm{H}_{2} \mathrm{SO}_{4}$, and $0.49 \mathrm{~h}^{-1}$ for cultivation on liquor hydrolysate obtained at $180{ }^{\circ} \mathrm{C} / 10$ $\mathrm{min} / 2.0 \% \mathrm{w} / \mathrm{w} \mathrm{H}_{3} \mathrm{PO}_{4}$, respectively. Xylose utilization was low $\left(0.01 \mathrm{~h}^{-1}\right)$ for both cultivations in the HRTB. Although a prolonged lag phase was detected in the HRTB, the growth rate had increased compared to cultivations in shake flasks, as well as ethanol conversion coefficient (16\% increase in HRTB for cultivation on liquor wheat straw hydrolysate obtained at $180{ }^{\circ} \mathrm{C} / 10 \mathrm{~min} / 0.5 \% \mathrm{w} / \mathrm{w} \mathrm{H}_{2} \mathrm{SO}_{4}$, and $18 \%$ increase in HRTB for cultivation on liquor wheat straw hydrolysates obtained at $180{ }^{\circ} \mathrm{C} / 10$ $\mathrm{min} / 2.0 \% \mathrm{w} / \mathrm{w} \mathrm{H}_{3} \mathrm{PO}_{4}$; Table 4). The ethanol productivity increased three-fold increase compared to cultivation on the sulphuric acid hydrolysates in shake flasks (VEP ${ }_{\text {flasks }}=0.05 \mathrm{~g} \mathrm{~L}^{-1} \mathrm{~h}^{-1}, \mathrm{VEP}_{\text {HRTB }}=$ $0.15 \mathrm{~g} \mathrm{~L}^{-1} \mathrm{~h}^{-1}$ ), and more than six-fold for cultivation on phosphoric acid hydrolysates $\left(\mathrm{VEP}_{\text {flasks }}=\right.$ $0.04 \mathrm{~g} \mathrm{~L}^{-1} \mathrm{~h}^{-1}, \mathrm{VEP}_{\mathrm{HRTB}}=0.25 \mathrm{~g} \mathrm{~L}^{-1} \mathrm{~h}^{-1}$; Table 4), respectively. Furthermore, bioprocess efficiency also increased in both cases (Table 4).

\section{Conclusions}

Based on the results of this research, it is evident that liquor wheat straw hydrolysate contains relatively high pentose sugar concentrations derived from hemicellulose and smaller glucose amounts. However, the liquor wheat straw hydrolysates also contain different concentrations of various by-products (e.g., furfural, hydroxymethylfurfural, formic, acetic and levulinic acids, and phenolic compounds derived from lignin) that can have a synergistic inhibitory effect on the growth and activity of $S$. cerevisiae yeast. Therefore, $S$. cerevisiae strain was selected for its tolerance toward inhibitors present in liquor wheat straw hydrolysate, and ability to use hexose and pentose sugars.

Anaerobic cultivations of this $S$. cerevisiae strain were performed in shake flasks on the liquor wheat straw hydrolysates media obtained by dilute sulphuric acid or phosphoric acid pre-treatment. The results showed that the modified yeast strain was able to resist the synergistic inhibitory effect of the by-products present in the liquor wheat straw hydrolysate, use glucose and xylose simultaneously, as well as grow and produce ethanol in these unfavourable conditions.

This research on bioethanol production on the optimized liquor wheat straw hydrolysate medium in the HRTB shows that the modified yeast strain improved xylose utilization compared to shake flasks experiments, resulting in total sugars utilization, and leading to an increase in overall bioprocess efficiency (Ethanol content $=3.99 \mathrm{~g} \mathrm{~L}^{-1}, Y_{\mathrm{E} \text {, sulphuric acid }}$ $=0.30 \mathrm{~g} \mathrm{~g}^{-1}$ and $E_{\text {sulphuric acid }}=58.82 \%$; Ethanol content $=4.55 \mathrm{~g} \mathrm{~L}^{-1}, Y_{\mathrm{E} \text {, phosphoric acid }}=0.45 \mathrm{~g} \mathrm{~g}^{-1}$ and $E_{\text {phosphoric acid }}=88.24 \%$ ). Thus, it is evident that the usage of genetically modified $S$. cerevisiae can improve the bioethanol production on the hydrolysates 
of lignocellulosic raw materials with relatively high xylose concentration through different levels of bioprocess optimization (e.g., pre-treatment conditions, selection of working microorganism, complete feedstock utilization, and bioprocess parameters).

\section{ACKNOWLEDGEMENTS}

This work was financed by the Croatian Scientific Foundation under the project "Sustainable production of bioethanol and biochemicals from agricultural waste lignocellulosic raw materials" (SPECH-LRM; No. 9158).

\section{Literature}

1. Sipos, B., Réczey J., Somorai, Z., Kádár, Z., Dienes, D., Réczey, K., Sweet sorghum as feedstock for ethanol production: Enzymatic hydrolysis of steam-pretreated bagasse, Appl. Biochem. Biotechnol. 153 (2008) 151. doi: https://doi.org/10.1007/s12010-008-8423-9

2. Morales, M., Quiintero, J., Conejeros, R., Aroca, G., Life cycle assessment of lignocellulosic bioethanol: Environmental impact and energy balance, Renew. Sust. Energ. Rev. 42 (2014) 1349.

doi: https://doi.org/10.1016/j.rser.2014.10.097

3. Van Dongen, F. E. M., Van Eylen, D., Kabel, M. A., Characterization of substituents in xylans from corn cobs and stover, Carbohyd. Polym. 86 (2011) 722. doi: https://doi.org/10.1016/j.carbpol.2011.05.007

4. Isikgor, H. F., Becer. C. R., Lignocellulosic biomass: A Sustainable platform for production of bio-based chemicals and polymers, Polym. Chem-UK. 6 (2015) 4497.

5. Adapa, P., Tabil, L., Schoenau, G., Compaction characteristics of barley, canola, oat and wheat straw, Byosys. Eng. 104 (2009) 335 doi: https://doi.org/10.1016/j.biosystemseng.2009.06.022

6. Malherbe, S., Cloete, T. E., Lignocellulose biodegradation: Fundamentals and applications, Rev. Environ. Sci. Biotech. 1 (2002) 105. doi: https://doi.org/10.1023/A:1020858910646

7. Saha, B. C., Iten, L. B., Cotta, M. A., Wu, Y. V., Dilute acid pretreatment, enzymatic saccharification and fermentation of wheat straw to ethanol, Process Biochem. 40 (2005) 3693. doi: https://doi.org/10.1016/j.procbio.2005.04.006

8. Pandey, A., Larroche, C., Ricke, S. C., Dussap, C.-G., Gnansounou, E., Biofuels alternative feedstocks and conversion processes. Elsevier Inc., Amsterdam, 2011.

9. Kumar, P., Barrett, D. M., Delwiche, M. J., Stroeve, P., Methods for pretreatment of lignocellulosic biomass for efficient hydrolysis and biofuel production, Ind. Eng. Chem. Res. 48 (2009) 3713. doi: https://doi.org/10.1021/ie801542g

10. Chen, X., Shekiro, J., Franden, M. A., The impacts of deacetylation prior to dilute acid pretreatment on the bioethanol process, Biotechnol. Biofuels 5 (2012). doi: https://doi.org/10.1186/1754-6834-5-8

11. Candido, R. G., Godoy, G. G., Goncalves, A. G., Study of sugarcane bagasse pretreatment with sulfuric acid as a step of cellulose obtaining, World Acad. Sci. Eng. Technol. 61 (2012) 101.
12. Agbor, V. B., Cicek, N., Sparling, R., Berlin, A., Levin, D. $B$., Biomass pretreatment: Fundamentals toward application, Biotechnol. Adv. 29 (2011) 675. doi: https://doi.org/10.1016/j.biotechadv.2011.05.005

13. Sanchez, O. J., Cordona C. A. Trends in biotechnological production off ethanol from different feed stocks, Bioresource Technol. 99 (2007) 5271.

14. Lenihan, P., Orozco, A., O'Neill, E., Ahmad, M. N. M., Rooney, D. W., Walker, D. M., Dilute acid hydrolysis of lignocellulosic biomass, Chem. Eng. J. 156 (2010) 395. doi: https://doi.org/10.1016/j.cej.2009.10.061

15. Palmqvist, E., Hahn-Hägerdal, B., Fermentation of lignocellulosic hydrolysates. I: inhibition and detoxification, Bioresour. Technol. 74 (2000) 17. doi: https://doi.org/10.1016/S0960-8524(99)00160-1

16. Tesfaw, A., Assefa., F., Current trends in bioethanol production by Saccharomyces cerevisiae: Substrate, inhibitor reduction, growth variables, coculture and immobilization, Int. Sch. Res. Notices 14 (2014) 1.

17. Helle, S., Cameron, D., Lam, J., White, B., Duff, S., Effect of inhibitory compounds found in biomass hydrolysates on growth and xylose fermentation by a genetically engineered strain of S. cerevisiae, Enzyme. Microb. Tech. 33 (2003) 786. doi: https://doi.org/10.1016/S0141-0229(03)00214-X

18. Sluiter, A., Hames, B., Ruiz, R., Scarlata, C., Sluiter, J., Templeton, D., Crocker, D., Determination of structural carbohydrates and lignin in biomass. Laboratory analytical procedure (LAP). NREL Technical Report, (2012).

19. Pavlečić, M., Vrana, I., Vibovec, K., Ivančić-Šantek, M., Horvat, P., Śantek, B., Ethanol production from different intermediates of sugar beet processing, Food Technol. Biotechnol. 48(3) (2010) 362.

20. Martinez, A., Rodriguez, M. E., York, S. W., Preston, J. F., Ingram, $L$. $O$., Use of UV absorbance to monitor furans in dilute acid hydrolysates of biomass, Biotechnol. Prog. 16(4) (2000) 637. doi: https://doi.org/10.1021/bp0000508

21. Polson, C., Sarkar, P., Incledon, B., Raguvaran, V., Grant, $R$., Optimization of protein precipitation based upon effectiveness of protein removal and ionization effect in liquid chromatography-tandem mass spectrometry, J. Chromatogr. B 785 (2003) 263. doi: https://doi.org/10.1016/S1570-0232(02)00914-5

22. Doran, P., Presentation and Analysis of Data. In: Bioprocess Engineering Principles, Doran, P. (Ed.), Academic Press Limited, London, UK (1998) 27-48.

23. Holwerda, E. K., Lynd, L. R., Testing alternative kinetic models for utilization of crystalline cellulose (Avicel) by batch cultures of Clostridium thermocellum, Biotechnol. Bioeng. 110(9) (2013) 2389. doi: https://doi.org/10.1002/bit.24914

24. Palmqvist, E., Hahn-Hagerdal, B., Fermentation of lignocellulosic hydrolysates. II: inhibitors and mechanisms of inhibition, Bioresource Technol. 74 (2000) 25. doi: https://doi.org/10.1016/S0960-8524(99)00161-3

25. Nieves, L. M., Panyon, L. A., Wang, X., Engineering sugar utilization and microbial tolerance toward lignocellulose conversion, Front. Bioeng. Biotechnol. 3 (2015) 17. doi: https://doi.org/10.3389/fbioe.2015.00017

26. Satimanont, S., Luengnaruemitchai, A., Wongkasemjit, S., Effect of temperature and time on dilute acid pretreatment of corn cobs. Int. J. Chem. Biol. Sci. 6(2012) 333.

27. Modig, T., Liden, G., Taherzadeh, M. J., Inhibition effects of furfural on alcohol dehydrogenase, aldehyde dehydrogenase and pyruvate dehydrogenase, Biochem. J. 363 (2002) 769.

doi: https://doi.org/10.1042/bj3630769 
28. Harmsen, P., Lips, S., Bakker, R., Pre-treatment of lignocellulose for biotechnological production of lactic acid, Food and Biobased Research (2013) 5.

29. Boguta, M., Bringel, F., Martinussen, J., Jensen, P. R., Screening of lactic acid bacteria for their potential as microbial cell factories for bioconversion of lignocellulosic feedstocks, Microb. Cell Fact. 13 (2014) 97. doi: https://doi.org/10.1186/s12934-014-0097-0

30. van der Pol, E. C., Vaessen, E., Weusthuis, R. A., Eggink, $G$., Identifying inhibitory effects of lignocellulosic by-products on growth of lactic acid producing micro-organisms using a rapid small-scale screening method, Biores. Technol. 209 (2016) 297. doi: https://doi.org/10.1016/j.biortech.2016.03.037

31. Kang, Q., Appels, L., Tan, T., Dewil, R. Bioethanol from lignocellulosic biomass: Current findings determine research priorities, Sci. World. J. 13 (2014) 1. doi: https://doi.org/10.1155/2014/298153

32. Okamoto, K., Uchii, A., Kanawaku, R., Yanase, H., Bioconversion of xylose, hexsose and biomass to ethanol by a new isolate of the white rot basidiomycete Trametes versicolor, Springer Plus 3 (2014) 121. doi: https://doi.org/10.1186/2193-1801-3-121

33. Lopes, D. D., Rosa, C. A., Hector, R. E., Dien, B. S., Mertens, J. A., Ayub, M. A. Z., Influence of genetic background of engineered xylose-fermenting industrial Saccharomyces cerevisiae strains for ethanol production from lignocellulosic hydrolysates, J. Ind. Microbiol. Biotechnol. 44(11) (2017) 1575. doi: https://doi.org/10.1007/s10295-017-1979-z

34. Novak, M., Trontel, A., Pavlečić, M., Mušak, L., Govedarica, D., Lauder, A., Ivančić, F., Šantek, B., Anaerobni uzgoj kvasca Saccharomyces cerevisiae na hidrolizatima lignoceluloznih sirovina. Cro. J. Food Technol. Biotechnol. Nutri. 12(1-2) (2017) 60 .

35. Casey, E., Sedlak, M., Ho, N. W. Y., Mosier, N. S., Effect of acetic acid and $\mathrm{pH}$ on the cofermentation of glucose and xylose to ethanol by a genetically engineered strain of Saccharomyces cerevisiae, FEMS Yeast Research 10 (2010) 385. doi: https://doi.org/10.1111/j.1567-1364.2010.00623.x
36. Almeida, J., Modig, T., Petersson, A., Hahna-Hagerdal, B. Liden, G., Gorwa-Grauslund, M. F., Increased tolerance and conversion of inhibitors in lignocellulosic hydrolysates by Saccharomyces cerevisiae, J. Chem. Technol. Biotechnol. 82 (2007) 340 doi: https://doi.org/10.1002/jctb.1676

37. Larsson, S., Palmqvist, E., Hahn Hägerdal, B., Tengborg, C., Stenberg, K., Zacchi. G., Nilvebrant, N. O., The generation of fermentation inhibitors during dilute acid hydrolysis of softwood, Enzyme Microbial. Technol. 24 (1999) 151. doi: https://doi.org/10.1016/S0141-0229(98)00101-X

38. Kim, D., Physico-chemical conversion of lignocellulose: Inhibitor effects and detoxification strategies: A mini review, Mol. 23(2) (2018) 309. doi: https://doi.org/10.3390/molecules23020309

39. Palmqvist, E., Halfdan, G., Meinander, Q. N., Hahn-Hägerdal, B., Main and interaction effects of acetic acid, furfural, and $p$-hydroxybenzoic acid on growth and ethanol productivity of yeasts, Biotech. Bioeng. 63 (1999) 46. doi: https://doi.org/10.1002/(SICI)1097-0290(19990405)63:1 $<46:$ :AID-BIT5>3.0.CO;2-J

40. Isikgor, F. H., Becer, C. R., Lignocellulosic biomass: A sustainable platform for the production of bio-based chemicals and polymers, Polym. Chem. 25 (2015) 4497. doi: https://doi.org/10.1039/C5PY00263J

41. Tengerdy, R. P., Szakacs, G., Bioconversion of lignocellulose in solid substrate fermentation, Biochemical Engineering Journal 13(2-3) (2003) 169. doi: https://doi.org/10.1016/S1369-703X(02)00129-8

42. Mussatto, S. I., Teixeira, J. A., Lignocellulose as raw material in fermentation processes. In: Current Research, Technology and Education Topics in Applied Microbiology and Microbial Biotechnology, (A. Mendez-Vilas, ed.), Formatex, Spain, 2010, 897-907.

43. Šantek, B., Ivančić, M., Horvat, P., Novak, S., Marić, V., Horizontal tubular bioreactors in biotechnology, Chem. Biochem. Eng. Q. 20 (2006) 389. 